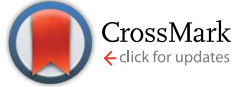

Cite this: Chem. Sci., 2016, 7, 596

Received 11th September 2015 Accepted 16th October 2015

DOI: $10.1039 / \mathrm{c} 5 \mathrm{sc} 03429 a$

www.rsc.org/chemicalscience

\section{Gold(III) tetraarylporphyrin amino acid derivatives: ligand or metal centred redox chemistry? $\uparrow$}

Sebastian Preiß, Jascha Melomedov, Anica Wünsche von Leupoldt and Katja Heinze*

Meso tetraarylporphyrinato gold(II) cations bearing different substituents at the aryl substituents (COOMe, $\mathrm{COOH}, \mathrm{NO}_{2}, \mathrm{NH}_{2}, \mathrm{NHAc}, \mathrm{H}, \mathrm{O}^{n} \mathrm{Bu}, \mathrm{CF}_{3}$ ) were prepared and characterised. Their reversible one-electron reductions were studied by (spectro)electrochemical means as well as by selective chemical oneelectron reduction using cobaltocene. The preferred location of the spin density, namely gold centred or porphyrin centred, was probed by electron paramagnetic resonance spectroscopy ( $g$ values, ${ }^{197} \mathrm{Au}$ hyperfine coupling) as well as by density functional theory calculations (spin densities). In all cases studied experimentally and theoretically, the gold(॥) valence isomer ( $5 d^{9}$ electron configuration) is preferred over the porphyrin $\pi$ radical anion. In the hexafluorophosphate salt of the nitro derivative a further nitro $\pi$ radical anion valence isomeric species is significantly populated. In the presence of chloride ions this nitro $\pi$ radical anion/Au" valence isomeric equilibrium evolves towards the porphyrin $\pi$ radical anion. The electronic structures of the nitro $\pi$ radical and the $A u^{\prime \prime} \sigma$ radical valence isomers $\left(5 d_{x^{2}-y^{2}}\right.$ orbital) could be calculated by DFT methods. The electron transfer pathway between the nitro $\pi$ radical anion and the $\mathrm{Au}^{\prime \prime}$ valence isomer is well described by the location of the hexfluorophosphate counterion, the $\mathrm{Au}-\mathrm{N}$ distances (corresponding to the totally symmetric stretching vibration), the symmetric stretching mode of the $\mathrm{NO}_{2}$ substituent and a meso-nitrophenyl rotation. The specific geometric and electronic properties of the favoured gold(॥) $\sigma$ radical valence isomer, namely counterion dislocation and $\sigma$ symmetry of the redox orbital, might stabilise charge-shifted states [(gold(॥) porphyrin)donor $^{\cdot+}$ ] by retarding the back electron transfer to give the ground state (gold(III) porphyrin)-donor. This will guide the design of (photo-induced) electron transfer pathways with tetraarylporphyrinato gold(III) complexes as electron acceptors.

\section{Introduction}

Synthetic metallo porphyrins are of increasing interest due to their suitability as chromophores, as well as electron and hole acceptors in artificial photosynthetic systems, ${ }^{1}$ due to their catalytic and sensing properties, ${ }^{2}$ due to their medical applications $^{3}$ as well as due to their propensity to stabilise unusual metal oxidation states. Specifically, porphyrinato gold(III) complexes have evolved as efficient anticancer drugs. ${ }^{4}$ Furthermore, they are catalysts for the cycloisomerization of allenones. ${ }^{5}$ Recently, gold clusters with face-on coordinated free-base porphyrins have been reported. ${ }^{6}$ Finally, gold(III) porphyrins are suitable ingredients in photoinduced electron

Institute of Inorganic Chemistry and Analytical Chemistry, Johannes Gutenberg-University of Mainz, Duesbergweg 10-14, 55128 Mainz, Germany. E-mail: katja.heinze@uni-Mainz.de; Fax: +49-6131-39-27277; Tel: +49-6131-39-25886

$\uparrow$ Electronic supplementary information (ESI) available: NMR and IR spectra, spectral changes upon reduction of $[\mathbf{A u}(\mathbf{T P P})]\left[\mathbf{P F}_{6}\right],[\mathbf{4 a}]\left[\mathbf{P F}_{6}\right],[\mathbf{4 b}]\left[\mathbf{P F}_{6}\right],[\mathbf{4 c}]\left[\mathbf{P F}_{6}\right]$, EPR spectra of 1a in the absence and presence of chloride, DFT calculations of Au(TPP), Cu(TPP), 4a, 4b and 4c, Cartesian coordinates of all optimised structures. See DOI: 10.1039/c5sc03429a acceptor. $^{7}$

The site of gold(III) porphyrin reduction, namely ligand or metal centred, has been discussed controversially. Based on early UV/Vis spectroscopic and theoretical studies the products of the reduction of gold(III) porphyrins had been described as porphyrin-centred $\pi$ radical anions. ${ }^{8}$ In a seminal paper, Kadish, Fukuzumi and Crossley provided compelling EPR spectroscopic evidence that the one-electron reduction of $\left[\mathbf{A}^{\mathbf{H}}\right]^{+}$to $\mathbf{A}^{\mathbf{H}}$ is metal centred giving gold(II) porphyrins (Scheme 1). ${ }^{9}$ Only a few ligand types, such as thiolates or thioethers, are capable to stabilise mononuclear gold in the oxidation state +II. ${ }^{10}$ Further outstanding examples are the fluorosulfate ${ }^{11}$ and xenon complexes $^{12}$ of $\mathrm{Au}^{\text {II }}$. Nitrogen donor ligands such as porphyrinato ligands have been reported to stabilise $\mathrm{Au}^{\mathrm{II}}$ with respect to disproportionation and dimerization ${ }^{9,13}$ to $\left[\mathrm{Au}_{2}^{\mathrm{II}}\right]$ species $^{14}$ as well (Scheme 1, A, B, $\left[\mathbf{C}^{+}\right]^{*}$ ). Disproportionation and dimerisation of $\left[\mathrm{Au}^{\mathrm{II}}(\mathrm{en})_{2}\right]^{2+} \mathbf{D}^{2+}$ has been suppressed by encapsulation in the pores of a zeolite $(\mathrm{en}=$ ethylenediamine $) .{ }^{15}$

The gold(II) porphyrin $\mathbf{A}^{\mathbf{H}}$ (Scheme 1) prepared by reduction of the corresponding gold(III) porphyrin cation $[\mathbf{A H}]^{+}$with the strongly reducing naphthalene radical anion yielded a broad transfer chains with the gold(III) porphyrin acting as electron 

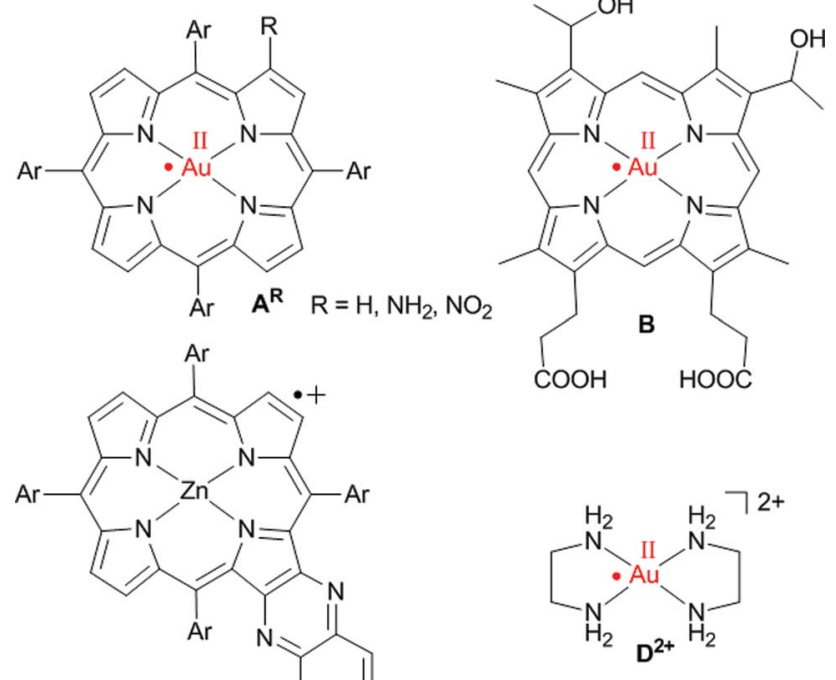

$\mathrm{Ar}=3,5-\left({ }^{t} \mathrm{Bu}\right)_{2} \mathrm{C}_{6} \mathrm{H}_{3}$
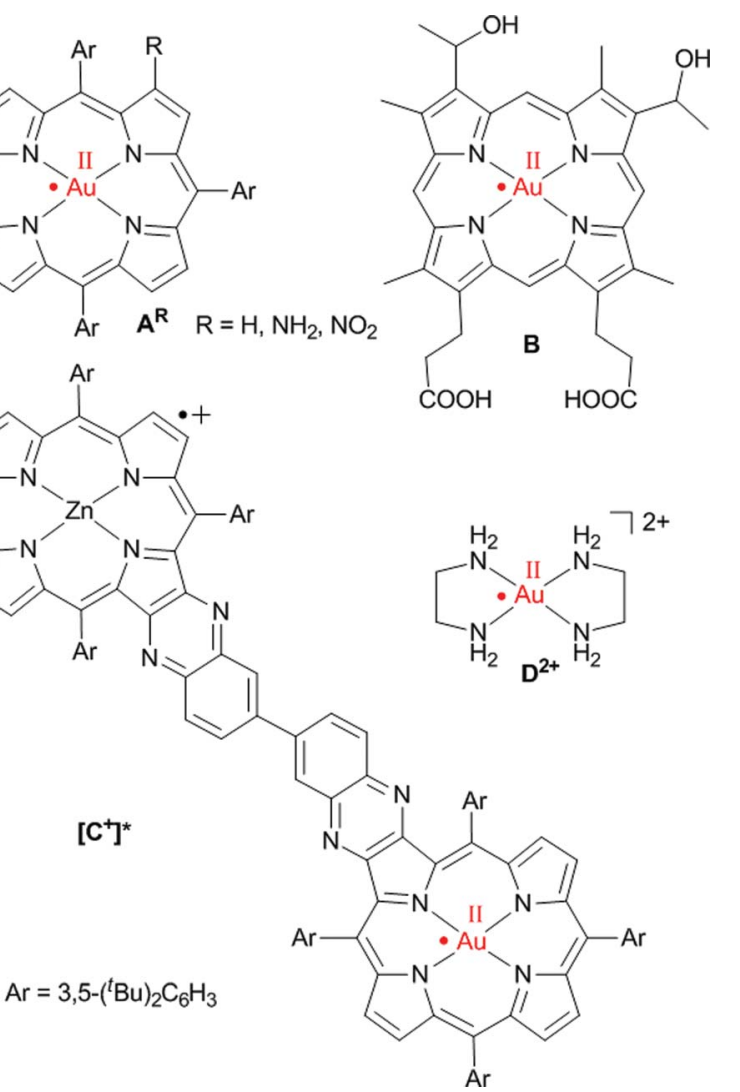

Scheme 1 Genuine mononuclear gold(॥) complexes with planar $\mathrm{N}_{4}$ coordination according to EPR spectroscopic results. ${ }^{9,13,15}$

EPR resonance centred at $g_{\text {av }}=2.06 .{ }^{9}$ Hyperfine coupling to ${ }^{197} \mathrm{Au}$ has been reported for the central $g$ line $\left[A\left({ }^{197} \mathrm{Au}\right)=27 \mathrm{G}\right.$ at $113 \mathrm{~K} ; I\left({ }^{197} \mathrm{Au}\right)=\frac{3}{2}$, natural abundance $\left.100 \%\right] \cdot{ }^{9}$ An EPR resonance with a significantly smaller peak-to-peak distance was observed for the gold(II) complex B of hematoporphyrin IX with $g_{\perp}=2.035, g_{\|}=1.970$ and $A_{\perp}\left({ }^{197} \mathrm{Au}\right)=A_{\|}\left({ }^{197} \mathrm{Au}\right)=15 \mathrm{G}$ at $130 \mathrm{~K}$ suggesting a less pronounced metal character (Scheme 1). ${ }^{13 b, e}$ The charge-shifted state $\left[\mathrm{C}^{+}\right]^{*}$ of a $\mathrm{Zn}^{\mathrm{II}}-\mathrm{Au}^{\mathrm{III}}$ bis(tetraarylporphyrin) $\mathrm{C}^{+}$yielded an EPR resonance with $g=2.182,2.043$, 1.979 and $A\left({ }^{197} \mathrm{Au}\right)=180,14$, n.r. $\mathrm{G}$ in frozen toluene solution at $143 \mathrm{~K}$ for the gold(II) centre (Scheme 1). ${ }^{\mathbf{1 3 d}}$ The gold complex $\left[\mathrm{Au}(\mathrm{en})_{2}\right]^{2+} \mathbf{D}^{2+}$ with the pure $\sigma$-donor ligand ethylenediamine trapped in a zeolite shows $g_{\|}=2.239, g_{\perp}=2.051, A_{\|}\left({ }^{197} \mathrm{Au}\right)=$ $188 \mathrm{G}$ and $A_{\perp}\left({ }^{197} \mathrm{Au}\right)=22 \mathrm{G}$ at room temperature (Scheme 1). ${ }^{15}$ Gold(III)-centred reductions have been associated with a significantly higher reorganization energy (ca. $1.25 \mathrm{eV})$ than porphyrin-based reductions $(c a .0 .6 \mathrm{eV}) .{ }^{13 c}$ The large reorganization energy renders gold(III) porphyrins suitable electron acceptors in photoelectron transfer schemes. ${ }^{7}$ Moreover, gold(III)-associated counterions should dissociate upon $\mathrm{Au}^{\mathrm{III}}$ to $\mathrm{Au}^{\mathrm{II}}$ reduction further retarding the back-electron transfer. For instance, chloride is associated to the $\mathrm{Au}^{\mathrm{III}}$ centre in solid AuCl(TPP) by electrostatic forces with a gold chloride distance of 3.01(1) A. ${ }^{16}$ Unfortunately, no solid structures of porphyrinato gold(II) complexes have been reported so far and further experimental or theoretical studies are lacking.
We had previously reported synthetically versatile mesosubstituted tetraaryl porphyrins with trans $-\mathrm{AB}_{2} \mathrm{C}$ substitution pattern including $\mathrm{A}=$ nitrophenyl, aminophenyl or amidophenyl, $\mathrm{C}=$ phenyl carboxylic acid or ester and B = EWG or EDG substituted aryl groups. ${ }^{17}$ These porphyrins can be metallated ${ }^{17}$ and assembled to multiporphyrin amides, ${ }^{17 b, 17 c}$ electron donor substituted amide-linked dyads ${ }^{\mathbf{1 7 a}}$ as well as electron donor (ferrocene) and electron acceptor (quinone) substituted amidelinked triads and tetrads ${ }^{\mathbf{1 7 b}}$ with well defined sequences from the N-terminus to the C-terminus. The different meso substituents of the porphyrin amino acids at the B position can be used to modulate the solubilities and to fine-tune the redox potentials which allows to design redox gradients. ${ }^{17}$

With this family of porphyrins in hand, we disclose in this contribution the factors that control the relative stabilities of a gold(II) porphyrin and its valence isomeric gold(III) porphyrin radical anion. We report novel meso-substituted $\mathrm{Au}^{\mathrm{III}}$ porphyrin amino acid derivatives with trans- $\mathrm{AB}_{2} \mathrm{C}$ substitution pattern for potential incorporation into electron transfer chains via amide bonds. These gold(III) porphyrins were inspected by cyclic voltammetry, UV/Vis spectroelectrochemistry and by EPR spectroscopy upon selective one-electron reduction with cobaltocene. We provide strong EPR and UV/Vis spectroscopic evidence that all singly reduced gold(III) porphyrins are well described as gold(II) porphyrins essentially irrespective of the meso-substituents $\mathrm{A}, \mathrm{B}$ and $\mathrm{C}$ and that the porphyrin radical anions are higher energy valence tautomers of the ground state $\mathrm{Au}^{\mathrm{II}}$ valence isomers. Detailed EPR parameters of the gold(II) porphyrinato complexes were obtained by spectral simulations of the experimental spectra ( $g$ tensors, (super)hyperfine couplings, valence isomer ratios). The experimental data are corroborated and interpreted with the aid of density functional theory (DFT) calculations in the framework of electron transfer theory.

\section{Results and discussion}

\section{Synthesis of free-base porphyrins and (porphyrinato)gold(III) complexes (series $[1 \mathrm{a}]^{+}-[3 \mathrm{a}]^{+}$and series $[4 \mathrm{a}]^{+}-[4 \mathrm{c}]^{+}$)}

The free-base porphyrins Ia-IVc were prepared according to literature procedures. ${ }^{17}$ Metallation of the free-base porphyrins was successful with potassium tetrachlorido aurate(III) in the presence of HOAc/NaOAc (Fleischer's route ${ }^{18}$ ), except for aminosubstituted porphyrin IIa (Scheme 2). Best yields were obtained using four equivalents of $\mathrm{KAuCl}_{4}$ giving the cationic aurated porphyrins as poorly soluble tetrachlorido aurate salts.

Auration of the amino-substituted porphyrin IIa with $\mathrm{KAuCl}_{4} / \mathrm{HOAc} / \mathrm{NaOAc}$ according to Fleischer's method resulted in acylation of the amino group. Auration of IIa according to Sauvage's protocol using $\left[\mathrm{Au}^{\mathrm{I}}(\mathrm{tht})_{2}\right]\left[\mathrm{BF}_{4}\right]$ followed by disproportionation to $\mathrm{Au}^{\mathrm{III}}$ and $\mathrm{Au}^{0}$ was unsuccessful as well (tht = tetrahydrothiophene). ${ }^{19}$ Thus, [2a] ${ }^{+}$was prepared via metallation and ion exchange of nitroporphyrin ester Ia to give [1a] $\left[\mathbf{P F}_{6}\right]$, followed by reduction of the nitro group of $[\mathbf{1 a}]^{+}$with $\mathrm{SnCl}_{2} / \mathrm{HCl}$ to give the aurated amino-substituted porphyrin [2a] Cl (Scheme 2). During this procedure, the gold(III) ion was neither reduced nor removed. Hence, the $\mathrm{Au}^{\mathrm{III}}$ porphyrins are 

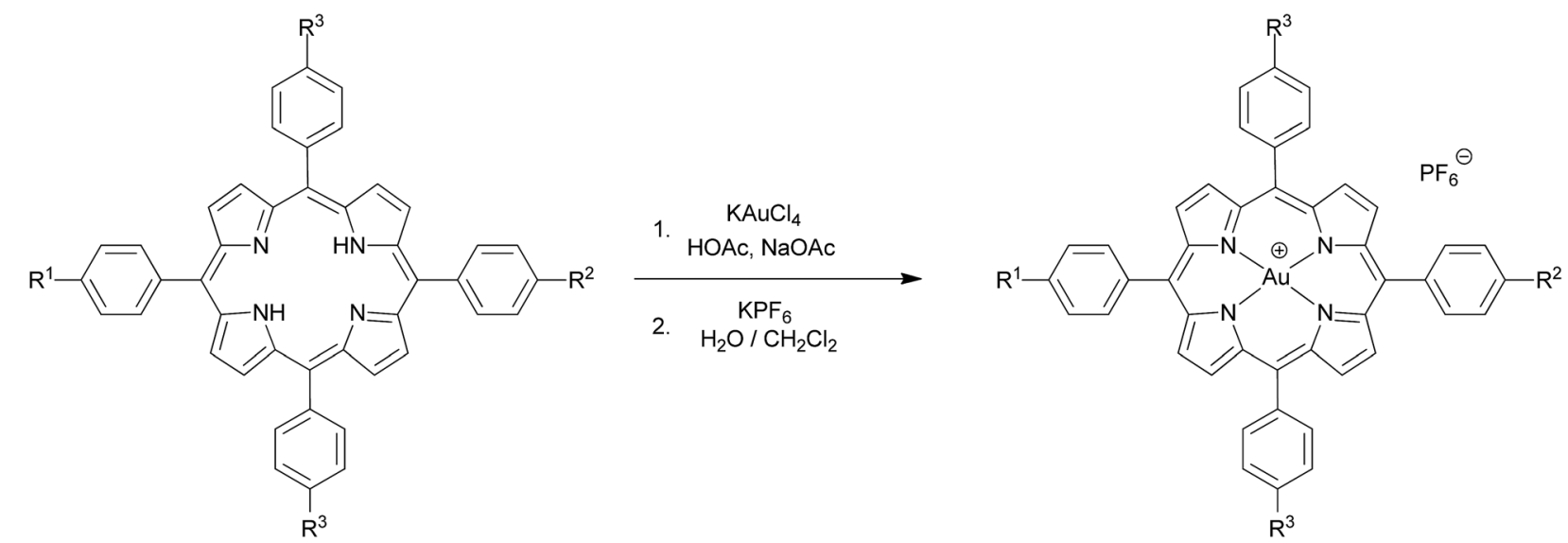

$$
\begin{aligned}
& \mathrm{H}_{2} \text { TPP: } A r^{1}=\mathrm{H} \\
& \mathrm{R}^{2}=\mathrm{H} \\
& \mathrm{R}^{3}=\mathrm{H} \\
& \mathrm{R}^{2}=\mathrm{NO}_{2} \quad \mathrm{R}^{3}=\mathrm{H}
\end{aligned}
$$

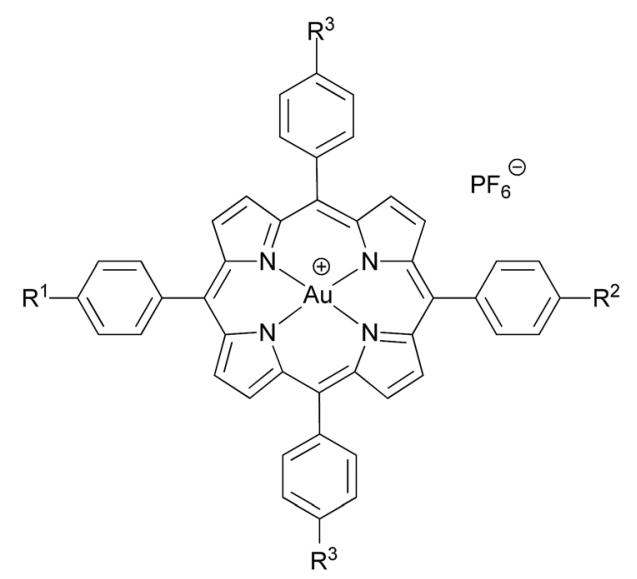

[1a] $]^{+}: \mathrm{R}^{1}=\mathrm{CO}_{2} \mathrm{Me} \quad \mathrm{R}^{2}=\mathrm{NO}_{2} \quad \mathrm{R}^{3}=\mathrm{H}$

$$
\begin{array}{ll}
\mathrm{R}^{2}=\mathrm{H} & \mathrm{R}^{3}=\mathrm{H} \\
\mathrm{R}^{2}=\mathrm{NO}_{2} & \mathrm{R}^{3}=\mathrm{H} \\
\mathrm{R}^{2}=\mathrm{NHCOMe} & \mathrm{R}^{3}=\mathrm{H} \\
\mathrm{R}^{2}=\mathrm{NHCOMe} & \mathrm{R}^{3}=\mathrm{H} \\
\mathrm{R}^{2}=\mathrm{NHCOMe} & \mathrm{R}^{3}=\mathrm{O}^{n} \mathrm{Bu} \\
\mathrm{R}^{2}=\mathrm{NHCOMe} & \mathrm{R}^{3}=\mathrm{CF}_{3}
\end{array}
$$

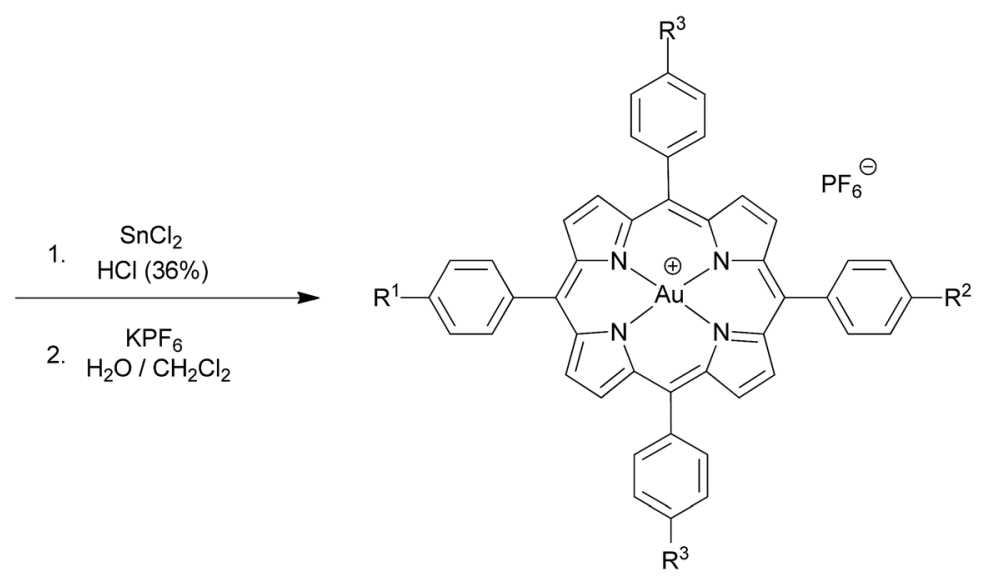

[2a] $]^{+}: \mathrm{R}^{1}=\mathrm{CO}_{2} \mathrm{Me} \quad \mathrm{R}^{2}=\mathrm{NH}_{2} \quad \mathrm{R}^{3}=\mathrm{H}$

Scheme 2 Synthesis of (porphyrinato)gold(III) complexes ([Au(TPP) $]^{+}$, series $[1 \mathrm{a}]^{+},[2 \mathrm{a}]^{+},[3 \mathrm{a}]^{+}$and series $\left.[4 \mathrm{a}]^{+},[4 \mathrm{~b}]^{+},[4 \mathrm{c}]^{+}\right)$.

stable under protic conditions. Counterion exchange of $[\mathrm{Au}($ porph $)]\left[\mathrm{AuCl}_{4}\right]$ or $[\mathbf{2 a}] \mathbf{C l}$ with $\mathrm{KPF}_{6}$ yielded the corresponding soluble hexafluorophosphate salts which are conveniently purified by column chromatography.

\section{Characterization of (porphyrinato)gold(III) complexes (series} $[1 \mathrm{a}]^{+}-[3 \mathrm{a}]^{+}$and series $\left.[4 \mathrm{a}]^{+}-[4 \mathrm{c}]^{+}\right)$

Ester-substituted complexes [1a][PF6]-[3a][PF6] are sufficiently soluble in dichloromethane. However, THF is required for acids $[\mathbf{4 b}]\left[\mathbf{P F}_{\mathbf{6}}\right]$ and $[\mathbf{4} \mathbf{c}]\left[\mathbf{P F}_{\mathbf{6}}\right]$ and even methanol is necessary for [4a] $\left[\mathbf{P F}_{6}\right]$ in order to acquire NMR spectra with a satisfactory signalto-noise ratio. This shows that the counterion and the meso substituents determine the solubility. All gold(III) complexes were characterised by ${ }^{1} \mathrm{H}$ NMR, ${ }^{13} \mathrm{C}$ NMR, ${ }^{31} \mathrm{P}$ NMR and $2 \mathrm{D}$ NMR spectroscopy, IR spectroscopy and high-resolution mass spectrometry. The proton NMR spectra display the expected number and intensities of resonances. The chemical shifts vary according to the substitution patterns paralleling the shifts of the corresponding free-base porphyrins Ia-IIIa and IVa-IVc. The $\mathrm{CH}_{3}$-ester, $\mathrm{NH}_{2}$-amine and $\mathrm{CH}_{3}$-amide substituents display characteristic resonances at $\delta=4.1,4.7,2.2 \mathrm{ppm}$, respectively. The $\left[\mathrm{PF}_{6}\right]^{-}$counterions show the characteristic septet at $\delta=$ $-144 \mathrm{ppm}$ in the ${ }^{31} \mathrm{P}$ NMR spectra. Upon auration the characteristic high-field pyrrol $\mathrm{NH}$ resonances of the free-base porphyrin disappear. Furthermore, auration of the free-base porphyrins consistently shifts the pyrrole $\mathrm{CH}$ proton resonances to lower field by $0.5 \mathrm{ppm}$, in accordance with the positive charge of the metal centre. In the IR spectra, characteristic absorptions for group vibrations are found for the ester, amine, amide, nitro, trifluoromethyl and acid substituents at around 1719, 1618, 1690, 1520/1346, 1324 and $1716 \mathrm{~cm}^{-1}$, respectively. The $\left[\mathrm{PF}_{6}\right]^{-}$counterions display absorptions for the PF stretching and deformation modes at 835-843 and 556-558 $\mathrm{cm}^{-1}$, respectively. ESI mass spectra fully confirm the integrity and stability of the complex cations displaying peaks at $\mathrm{m} / \mathrm{z}$ values corresponding to the intact complex cation (see Exp. section). 
With the exception of the electron-rich $\mathrm{R}^{3}=\mathrm{O}^{n} \mathrm{Bu}$ substituted complex [4b] ${ }^{+}$all gold(III) porphyrinato complexes $[1 \mathbf{a}]^{+},[2 \mathrm{a}]^{+},[3 \mathrm{a}]^{+},[\mathbf{4 a}]^{+}$and $[\mathbf{4 c}]^{+}$show hypsochromically shifted Soret bands as compared to their corresponding free-base porphyrins Ia, IIa, IIIa, IVa and IVe (hypso porphyrins ${ }^{8 b}$ ). In all cases, the number of $\mathrm{Q}$ bands is reduced from four to two (or even to one) as expected for metalloporphyrins with local $D_{4 \mathrm{~h}}$ symmetry of the porphyrin core. Expectedly, gold(III) porphyrinato complexes are non-emissive at room temperature in fluid solution as exemplarily checked for $[\mathbf{1} \mathbf{a}]\left[\mathbf{P F}_{6}\right],[3 \mathbf{a}]\left[\mathbf{P F}_{6}\right]$ and $[\mathbf{4 c}]$ $\left[\mathrm{PF}_{6}\right]^{8,20}$

\section{Redox chemistry of (porphyrinato)gold(III) complexes (series} $[1 \mathrm{a}]^{+}-[3 \mathrm{a}]^{+}$and series $\left.[4 \mathrm{a}]^{+}-[4 \mathrm{c}]^{+}\right)$

Several reversible reductions are observed for cations $[\mathbf{1 a}]^{+}$, $[2 \mathrm{a}]^{+},[3 \mathrm{a}]^{+},[4 \mathbf{b}]^{+}$and $[4 \mathbf{c}]^{+} 10^{-3} \mathrm{M}$ in $0.1 \mathrm{M}\left[{ }^{n} \mathrm{Bu}_{4} \mathrm{~N}\right]\left[\mathrm{PF}_{6}\right] / \mathrm{THF}$ solution (Fig. 1 and 2, Table 1). For solubility reasons complex $[4]^{+}$was measured in $\mathrm{MeOH}$ and the solvent window of $\mathrm{MeOH}$ allows for only a single reversible reduction wave to be observed (Fig. 2, Table 1). All potentials are given relative to the ferrocene/ ferrocenium couple. As expected from substituent effects, $[\mathbf{1 a}]^{+}$ is more easily reduced to $1 \mathrm{a}(-0.92 \mathrm{~V})$ than $[\mathbf{A u}(\mathbf{T P P})]^{+}$to $\mathbf{A u}(\mathbf{T P P})(-0.97 \mathrm{~V})$, while $[2 \mathrm{a}]^{+}(-0.99 \mathrm{~V})$ is more difficult to reduce. Similarly, the potentials shift to more negative values in the series $[4 \mathrm{c}]^{+}(-1.00 \mathrm{~V}),[4 \mathrm{a}]^{+}(-1.02 \mathrm{~V})$ and $[4 \mathrm{~b}]^{+}(-1.08 \mathrm{~V})$, which is again explicable by the increasing electron donating

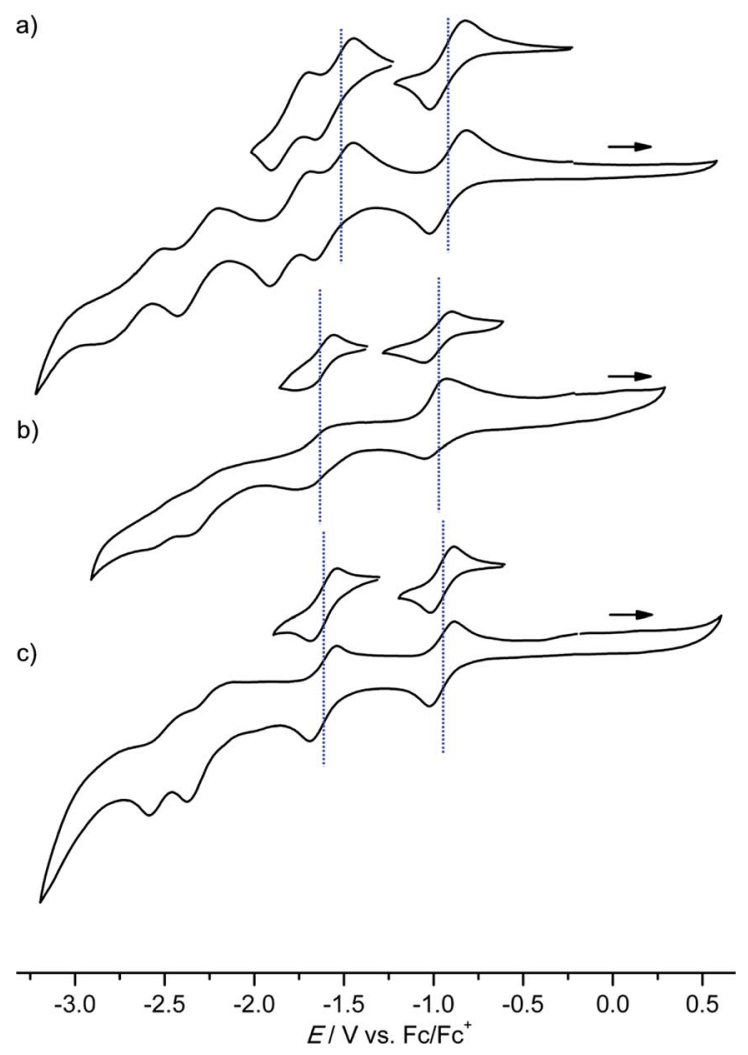

Fig. 1 Cyclic voltammograms of (a) $[1 \mathrm{a}]^{+}$, (b) [2a] ${ }^{+}$and (c) $[3 \mathrm{a}]^{+} 10^{-3} \mathrm{M}$ in $0.1 \mathrm{M}\left[{ }^{n} \mathrm{Bu}_{4} \mathrm{~N}\right]\left[\mathrm{PF}_{6}\right] / \mathrm{THF}$ solution; potentials referenced against the ferrocene/ferrocenium couple.
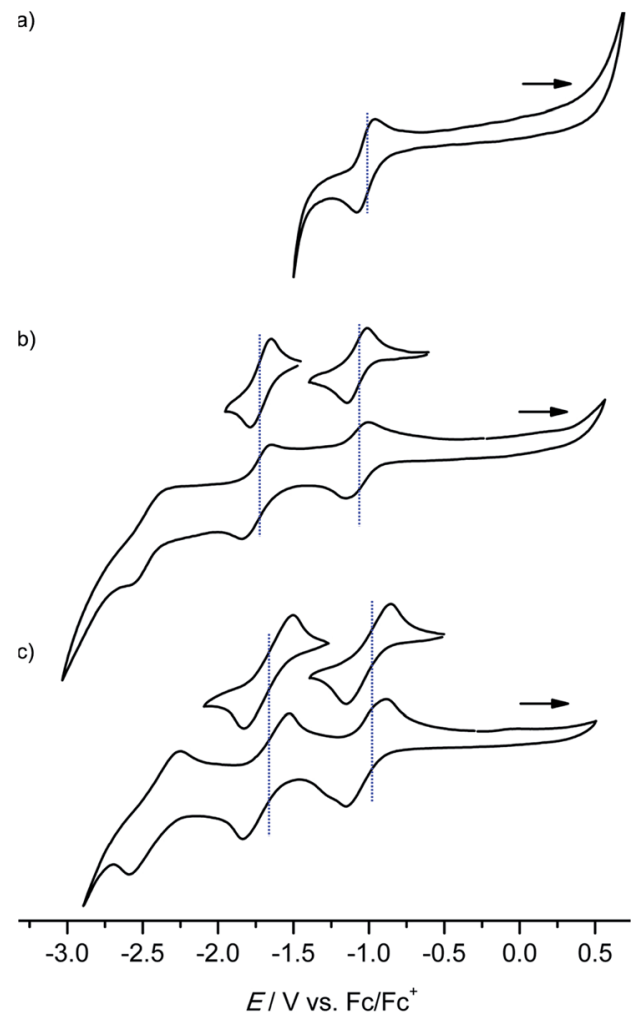

Fig. 2 Cyclic voltammograms of (a) $[4 a]^{+}(\mathrm{MeOH}),(b)[4 b]^{+}$and (c) $[4 \mathrm{c}]^{+} 10^{-3} \mathrm{M}$ in $0.1 \mathrm{M}\left[{ }^{n} \mathrm{Bu}_{4} \mathrm{~N}\right]\left[\mathrm{PF}_{6}\right] / \mathrm{THF}$ solution; potentials referenced against the ferrocene/ferrocenium couple.

nature of the substituents $\left(\mathrm{CF}_{3}, \mathrm{H}, \mathrm{O}^{n} \mathrm{Bu}\right)$. Similar to the corresponding free-base porphyrins the shifts are only small. ${ }^{17}$ The second reduction is especially facile with the electron withdrawing $\mathrm{NO}_{2}$ substituent $\left(\mathbf{1 a} /[\mathbf{1 a}]^{-} ;-1.55 \mathrm{~V}\right)$. The nitro derivative $[\mathbf{1 a}]^{+}$shows even further reversible reductions. Hence, one of the $[\mathbf{1 a}]^{+}$reductions might be associated to the nitro substituent itself (vide infra).

The differences between the first and second reduction potentials amount to $0.60-0.68 \mathrm{~V}$ which corresponds to very high comproportionation constants of $K_{\mathrm{C}}>10^{10}$ for the neutral complexes. $^{21}$ Hence, disproportionation of the neutral complexes into the corresponding cations and anions can be safely neglected and spectral signatures after one-electron reduction will essentially be associated with the neutral complexes.

All gold(III) complexes were reduced electrochemically to the neutral species in an optically transparent thin layer electrochemical (OTTLE) cell using THF as solvent (MeOH for [4a] $]^{+}$). In all cases, isosbestic points were observed corroborating the reversible nature of the first reduction process (Fig. 3 and ESI $\dagger$ ). The shifts of the Soret and Q bands as well as the observed isosbestic points closely resemble those found for the $[\mathbf{A u}(\mathbf{T P P})]^{+} / \mathbf{A u}(\mathbf{T P P})$ process in THF (ESI $\dagger$ ) and in pyridine ${ }^{13 c}$ or in PhCN. ${ }^{9}$ In all cases, except for the $[\mathbf{2 a}]^{+} / \mathbf{2 a}$ and $[\mathbf{4} \mathbf{b}]^{+} / \mathbf{4} \mathbf{b}$ redox couples with the strongly electron-donating $\mathrm{NH}_{2}$ and $\mathrm{O}^{n} \mathrm{Bu}$ substituents, the intensity of the Soret band decreases while for $[\mathbf{2 a}]^{+} / \mathbf{2 a}$ and $[\mathbf{4 b}]^{+} / \mathbf{4 b}$ the intensity increases (Fig. 3b and ESI $\dagger$ ). A 
Table 1 Redox potentials (peak potentials in parentheses) of porphyrinato gold(II) complexes measured $10^{-3} \mathrm{M}^{\text {in }} 0.1 \mathrm{M}\left[{ }^{n} \mathrm{Bu}_{4} \mathrm{~N}\right]\left[\mathrm{PF}_{6}\right] / \mathrm{THF}$ solution, potentials given relative to ferrocene/ferrocenium

\begin{tabular}{|c|c|c|c|c|}
\hline & $E_{\frac{1}{2}}\left([\mathrm{Au}(\mathrm{P})]^{+} / \mathrm{Au}(\mathrm{P})\right)$ & $E_{\frac{1}{2}}\left(\mathrm{Au}(\mathrm{P}) /[\mathrm{Au}(\mathrm{P})]^{-}\right)$ & $E_{\frac{1}{2}}\left([\mathrm{Au}(\mathrm{P})]^{-} /[\mathrm{Au}(\mathrm{P})]^{2-}\right)$ & $E_{\frac{1}{2}}\left([\mathrm{Au}(\mathrm{P})]^{2-} /[\mathrm{Au}(\mathrm{P})]^{3-}\right)$ \\
\hline$[\mathrm{Au}(\mathrm{TPP})]\left[\mathrm{PF}_{6}\right]$ & $-0.97(-1.06 /-0.88)$ & $-1.65(-1.73 /-1.57)$ & $-2.34(-2.43 /-2.25)$ & - \\
\hline $1 \mathrm{a}\left[\mathrm{PF}_{6}\right]$ & $-0.92(-1.02 /-0.82)$ & $-1.55(-1.66 /-1.44)$ & $-1.80(-1.90 /-1.70)$ & $-2.31(-2.42 /-2.20)$ \\
\hline $3 \mathrm{a}\left[\mathrm{PF}_{6}\right]$ & $-0.96(-1.02 /-0.89)$ & $-1.63(-1.70 /-1.55)$ & $-2.28(-2.37 /-2.19)$ & $-2.50(-2.58 /-2.41)$ \\
\hline $4 \mathrm{a}\left[\mathrm{PF}_{6}\right]^{a}$ & $-1.02(-1.08 /-0.96)$ & $b$ & $b$ & $b$ \\
\hline $4 \mathrm{~b}\left[\mathrm{PF}_{6}\right]$ & $-1.08(-1.15 /-1.01)$ & $-1.72(-1.79 /-1.65)$ & $-2.46(-2.57 /-2.34)$ & \\
\hline
\end{tabular}

${ }^{a}$ In MeOH. ${ }^{b}$ Outside solvent window.

similar hyperchromic effect has been observed for the $\left[\mathbf{A}^{\mathbf{N H} 2}\right]^{+} /$ $\mathbf{A}^{\mathbf{N H} 2}$ couple with the amino group attached to a porphyrin beta position. ${ }^{13 c}$

For chemical reductions, the gold(III) porphyrin complexes were dissolved in $\mathrm{CH}_{2} \mathrm{Cl}_{2}\left([\mathbf{1 a}]\left[\mathbf{P F}_{\mathbf{6}}\right]-[\mathbf{1} \mathbf{c}]\left[\mathbf{P F}_{\mathbf{6}}\right]\right)$, THF $\left([\mathbf{4 b}]\left[\mathbf{P F}_{\mathbf{6}}\right] /\right.$ $\left.[\mathbf{4 c}]\left[\mathbf{P F}_{6}\right]\right)$ or $\mathrm{MeOH}\left([\mathbf{4 a}]\left[\mathbf{P F}_{\mathbf{6}}\right]\right)($ ca. $5 \mathrm{mM})$. In order to definitely

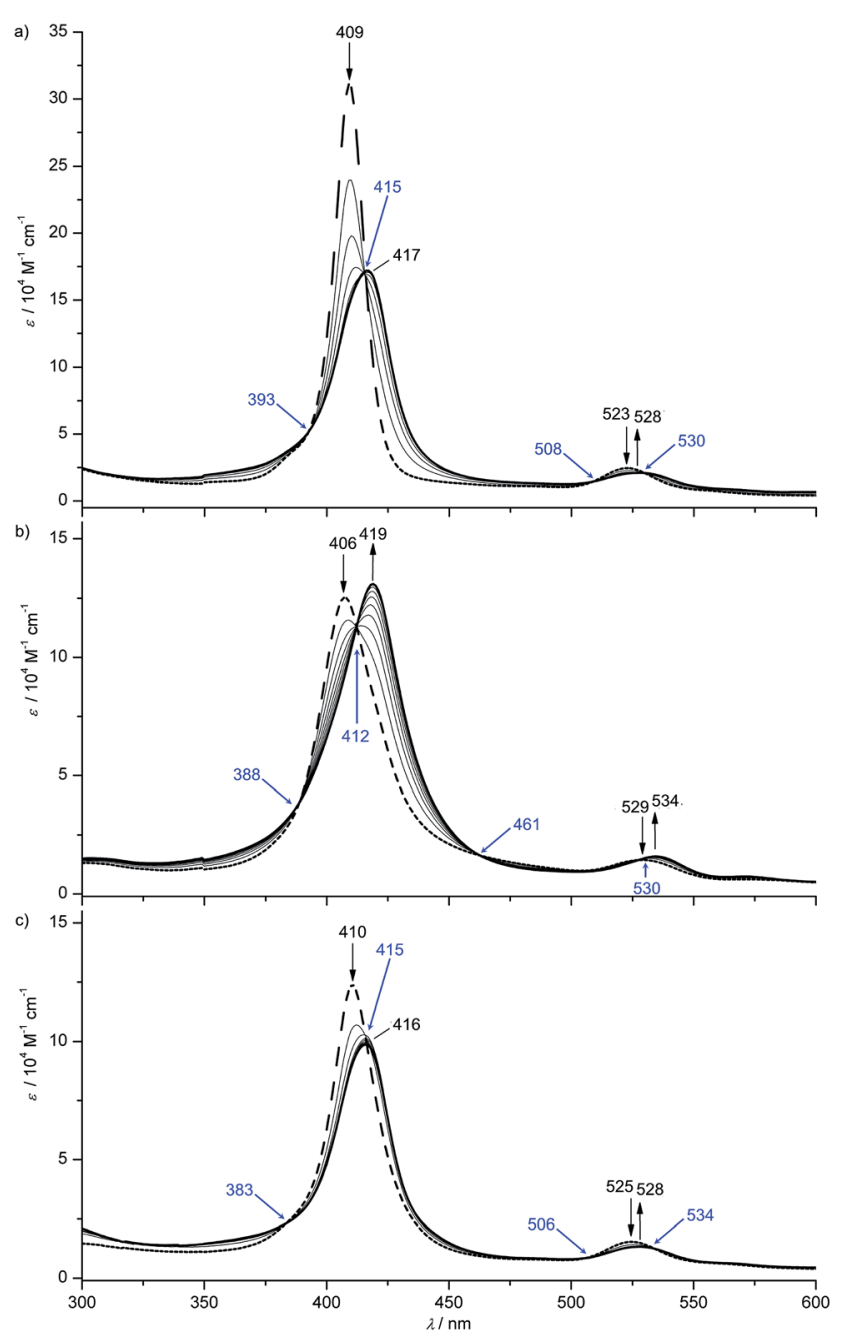

Fig. 3 UV/Vis spectral changes upon the first electroreduction of (a) $[1 \mathrm{a}]^{+}$, (b) $[2 \mathrm{a}]^{+}$and (c) $[3 \mathrm{a}]^{+}$in $0.1 \mathrm{M}\left[{ }^{n} \mathrm{Bu}_{4} \mathrm{~N}\right]\left[\mathrm{PF}_{6}\right] / \mathrm{THF}$ solution (isosbestic points indicated in blue). prevent overreduction, these solutions were treated with slightly substoichiometric amounts of $\mathrm{CoCp}_{2}\left(E_{\frac{1}{2}}=-1.33 \mathrm{~V}\right.$ in $\mathrm{CH}_{2} \mathrm{Cl}_{2}$ vs. $\mathrm{Fc} / \mathrm{Fc}^{+}$(ref. 22)) in an EPR tube. The redox potential of $\mathrm{CoCp}_{2}$ is perfectly in-between the first and second reduction of the gold porphyrins (Fig. 1 and 2) further avoiding over-reduction. The reaction mixture in the tube was immediately frozen by immersing into liquid nitrogen and subjected to X-band EPR spectroscopy. Hence, we obtained significantly better resolved EPR spectra than previously reported for neutral porphyrinato gold complexes prepared by reduction of $\left[\mathbf{A}^{\mathbf{H}}\right]^{+}$with the strongly reducing naphthalene radical anion in DMF (ca. $-3 \mathrm{~V} v s . \mathrm{Fc} / \mathrm{Fc}^{+}$ (ref. 22)). ${ }^{9}$ In this case some over-reduction might have been occurred blurring the hyperfine couplings to gold and nitrogen nuclei.

Indeed, Au(TPP) as prepared by reduction of $[\mathbf{A u}(\mathbf{T P P})]^{+}$by CoCp 2 in $\mathrm{CH}_{2} \mathrm{Cl}_{2}$ shows a well-resolved EPR pattern which could be reasonably simulated by a rhombic $g$ tensor with hyperfine interaction to a single ${ }^{197} \mathrm{Au}$ nucleus $\left(I=\frac{3}{2}\right.$; natural abundance $100 \%)$ and superhyperfine coupling to four ${ }^{14} \mathrm{~N}$ nuclei $(I=1$, natural abundance $99.6 \%$ ). The high resolution allows a very good estimation of the high-field parameters while the low-field parameters are less well-resolved (Table 2, Fig. 4). Compared to the isoelectronic $\mathbf{C u}(\mathbf{T P P})$ complex $\left({ }^{63 / 65} \mathrm{Cu} ; I=\frac{3}{2}\right.$; combined natural abundance $\left.100 \% ; g_{1}=2.197, g_{2}=g_{3}=2.054\right)^{17 d}$ the metal coupling constant $A_{1}\left[A_{1}\left({ }^{197} \mathrm{Au}\right)=43 \mathrm{G} ; A_{1}\left({ }^{63 / 65} \mathrm{Cu}\right)=197\right.$ $\mathrm{G}$ (ref. $17 d$ )] is significantly reduced in Au(TPP). This suggests a more covalent character of the $\mathrm{Au}^{\mathrm{II}}-\mathrm{N}$ bonds compared to the $\mathrm{Cu}^{\mathrm{II}}-\mathrm{N}$ bonds in their respective $\mathrm{TPP}^{2-}$ complexes. For $\left[\mathrm{C}^{+}\right]^{*}$ with strongly electron donating meso substituents at the gold porphyrin a much larger hfc to ${ }^{197} \mathrm{Au}$ has been reported $\left[A_{1}\left({ }^{197} \mathrm{Au}\right)=180 \mathrm{G}\right] \cdot{ }^{13 d}$ In accordance with the stronger nephelauxetic effect of porphyrins, complex $\mathbf{D}^{2+}$ with the pure $\sigma$ donor ligand ethylenediamine features a significantly larger hyperfine coupling to ${ }^{197} \mathrm{Au}$ than Au(TPP) as well. ${ }^{15}$

For complexes 1a-3a the broad EPR resonance corresponding to the $\mathrm{Au}^{\mathrm{II}}$ valence isomer is less well resolved due to the lower symmetry and hence different superhyperfine interactions (Fig. 5). Furthermore, the broad $\mathrm{Au}^{\mathrm{II}}$ resonance is superimposed by a sharp slightly rhombic resonance around $g=2.0$. For $2 \mathbf{a}$ and $3 \mathbf{3 a}$, this sharp resonance accounts for approximately $5-6 \%$ of the total EPR intensity. The pattern can be satisfactorily simulated by $g_{1,2,3}=2.018,2.005,1.994$ and hyperfine coupling to four nitrogen atoms $\left(A_{1,2,3}=1,12,1 \mathrm{G}\right)$. These data fit to 
Table 2 X-band EPR data of one-electron reduced porphyrinato gold(III) complexes obtained from simulations of the experimental spectra

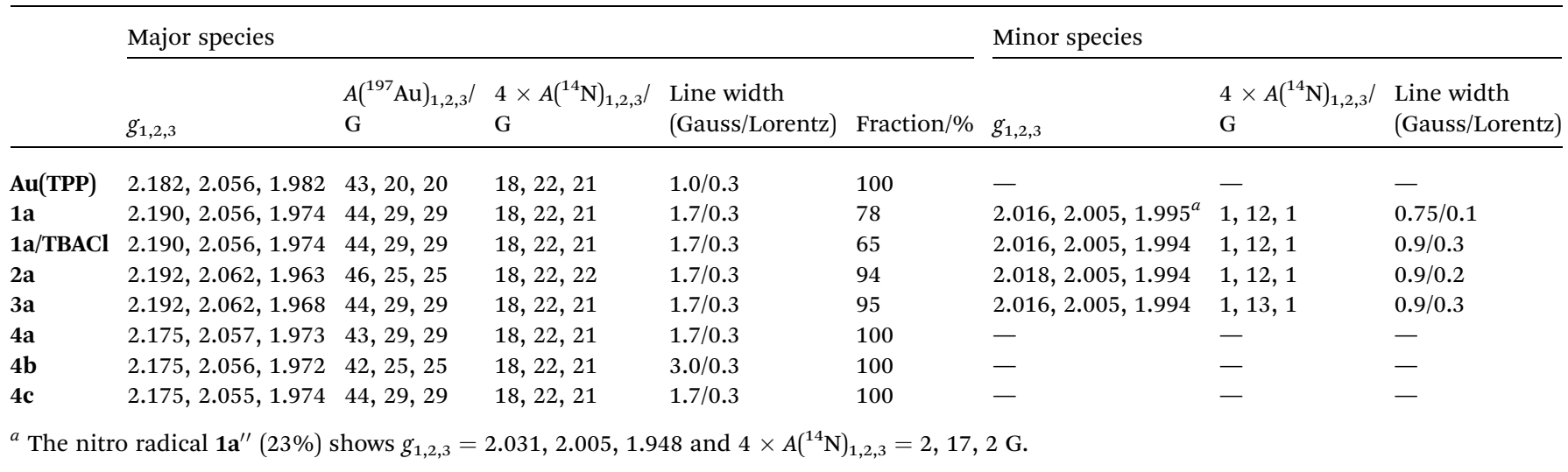

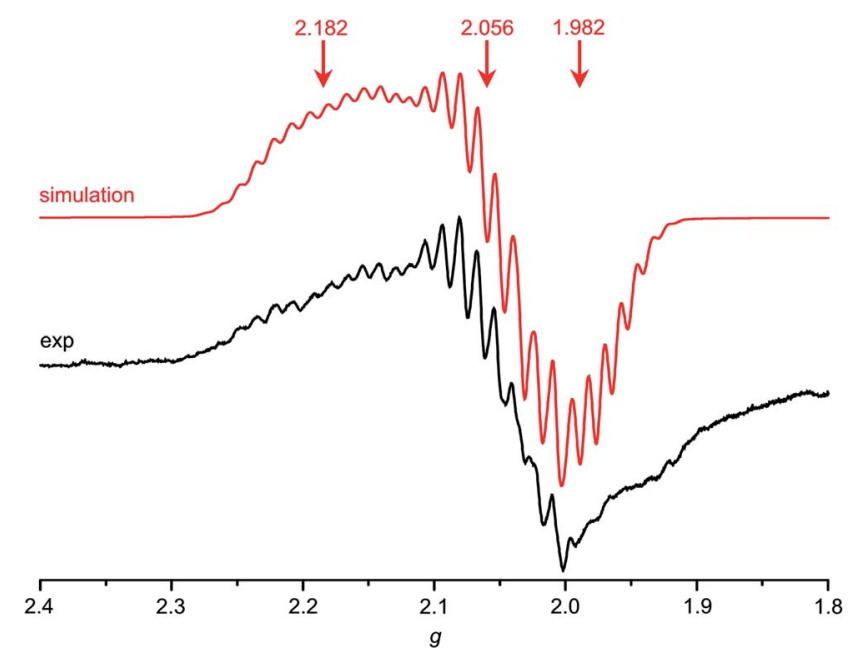

Fig. $4 \mathrm{X}$-band EPR spectrum of $\mathrm{Au}$ (TPP) in frozen $\mathrm{CH}_{2} \mathrm{Cl}_{2}$ solution $(77 \mathrm{~K}, 9.4 \mathrm{GHz})$ and corresponding simulation.

gold(III) porphyrin radical anions $\mathbf{2} \mathbf{a}^{\prime}$ and $\mathbf{3} \mathbf{a}^{\prime}$. For $\mathbf{4 a}-\mathbf{4 c}$ prepared in $\mathrm{THF}$ or $\mathrm{MeOH}$, the corresponding gold(III) porphyrin radical anions $\mathbf{4} \mathbf{a}^{\prime}, \mathbf{4} \mathbf{b}^{\prime}$ and $\mathbf{4} \mathbf{c}^{\prime}$ are only present in negligible amounts (Fig. 6). Hence, in all these cases the equilibrium between the gold(II) valence isomers $\mathbf{2 a - 4 c}$ and their corresponding porphyrin radical anions $2 \mathbf{a}^{\prime}-\mathbf{4} \mathbf{c}^{\prime}$ is in favour of the gold(II) isomers. The very strong preference of $\mathbf{4 a - 4 c}$ over $\mathbf{4} \mathbf{a}^{\prime}-\mathbf{4} \mathbf{c}^{\prime}$ independent of the meso substituents might be due to a solvent effect overwhelming the substituent effects. Indeed, in THF or in $\mathrm{MeOH}$ solvent-separated ion-pairs $[\mathbf{4 a - 4 c}]^{+} / /\left[\mathbf{P F}_{\mathbf{6}}\right]^{-}$ should be present while in $\mathrm{CH}_{2} \mathrm{Cl}_{2}$ solution contact ion pairs of $[\mathbf{2 a}, \mathbf{3 a}]\left[\mathbf{P F}_{\mathbf{6}}\right]$ are formed. Indeed, reduction of $[\mathbf{2 a}]\left[\mathbf{P F}_{\mathbf{6}}\right]$ or $[\mathbf{3 a}]$ $\left[\mathbf{P F}_{6}\right]$ in THF resulted in EPR spectra mainly displaying the gold(II) valence isomers (ESI, Fig. S29 and S30 $\dagger$ ). The counterion location might affect the charge and spin distribution in the neutral species as well (vide infra).

The much more intense sharp EPR resonance present in the EPR spectrum of $\mathbf{1 a}$ obtained from $[\mathbf{1 a}]\left[\mathbf{P F}_{\mathbf{6}}\right]$ in $\mathrm{CH}_{2} \mathrm{Cl}_{2}$ (Fig. 5a) differs from the sharp resonances assigned to the porphyrin $\pi$ radical anions $\mathbf{2} \mathbf{a}^{\prime}$ and $\mathbf{3} \mathbf{a}^{\prime}$. Indeed, simulations of the resonance suggests the presence of a further radical species with $g_{1,2,3}=$
2.031, 2.005, 1.948 and hyperfine coupling to a single nitrogen atom $\left(A_{1,2,3}=2,17,2 \mathrm{G}\right)$. This is in good accordance with a nitroarene radical anion. ${ }^{23}$ Hence, this distinct EPR resonance is assigned to a nitrophenyl radical anion valence isomer $\mathbf{1 a}^{\prime \prime}$. The radical distribution $\mathbf{1 a}: \mathbf{1 a}^{\prime}: \mathbf{1 a}^{\prime \prime}$ is estimated as $78: 3: 19$. The decomposition into the component spectra is displayed in the ESI. $\dagger$ The effect of the type of counterions was probed by adding two equivalents of $\left[{ }^{n} \mathrm{Bu}_{4} \mathrm{~N}\right] \mathrm{Cl}$ to the solution prior to reduction of the gold(III) porphyrin with $\mathrm{CoCp}_{2}$. No significant changes are observed for $\mathbf{A u}(\mathbf{T P P}), \mathbf{3 a}\left(\mathrm{CH}_{2} \mathrm{Cl}_{2}\right)$ or $\mathbf{4 c}$ (THF) in the presence of chloride. However, the presence of chloride transforms the 1a : 1a' $: \mathbf{1 a}^{\prime \prime}$ radical mixture almost completely into a 1a : 1a' mixture (65:35) as only the gold(II) resonance and the porphyrin radical anion resonance are observed under these conditions (ESI, $\dagger$ Table 2), similar to the $2 \mathbf{a}^{\prime}$ and $\mathbf{3} \mathbf{a}^{\prime}$ cases. Hence, for the nitro derivative 1a, three possible valence isomers are possible: the gold(II) radical (1a), the porphyrin based $\pi$ radical $\left(\mathbf{1 a}^{\prime}\right)$ and a further nitro group based $\pi$ radical $\left(\mathbf{1 a}^{\prime \prime}\right)$. Assuming, that rapid freezing does not strongly affect the equilibria of valence isomers, we can conclude that the environment, namely anions and the solvent, appears to influence these valence isomeric equilibria significantly. The substituents influence the equilibria as well, especially, when a strongly electron accepting nitro group is present. A conceivable intervalence transition between $1 \mathbf{a}$ and $\mathbf{1} \mathbf{a}^{\prime} / \mathbf{1 a}^{\prime \prime}$ is not detected in the UV/Vis spectrum by comparison with the spectra of $2 \mathbf{a}$ and $3 \mathbf{a}$ (Fig. 3). This might be associated with the different orbital symmetries of $\mathbf{1 a}$ and $\mathbf{1} \mathbf{a}^{\prime} / \mathbf{1} \mathbf{a}^{\prime \prime}$.

The electronic structure of the gold(II) radicals $1 \mathbf{1 a}-\mathbf{4 c}$, the valence isomeric equilibrium $\mathbf{1 a} / \mathbf{1} \mathbf{a}^{\prime \prime}$ and the effect of counterions will be addressed by theoretical methods in the next section.

DFT studies of (porphyrinato)gold(III) complexes (series [1a $]^{+}-$ $[3 \mathrm{a}]^{+}$and series $\left.[4 \mathrm{a}]^{+}-[4 \mathrm{c}]^{+}\right)$and the corresponding reduced species (series 1a-3a and series $4 a-4 c$ )

Both the geometries of the cationic gold(III) porphyrins $[\mathbf{A u}(\mathbf{T P P})]^{+},[\mathbf{1 a}]^{+}-[\mathbf{4 c}]^{+}$and the structures of all corresponding neutral species Au(TPP), 1a-3a and $\mathbf{4 a - 4 c}$ were optimised by DFT methods (B3LYP, LANL2DZ, IEFPCM $\mathrm{CH}_{2} \mathrm{Cl}_{2}$; Table 3, 

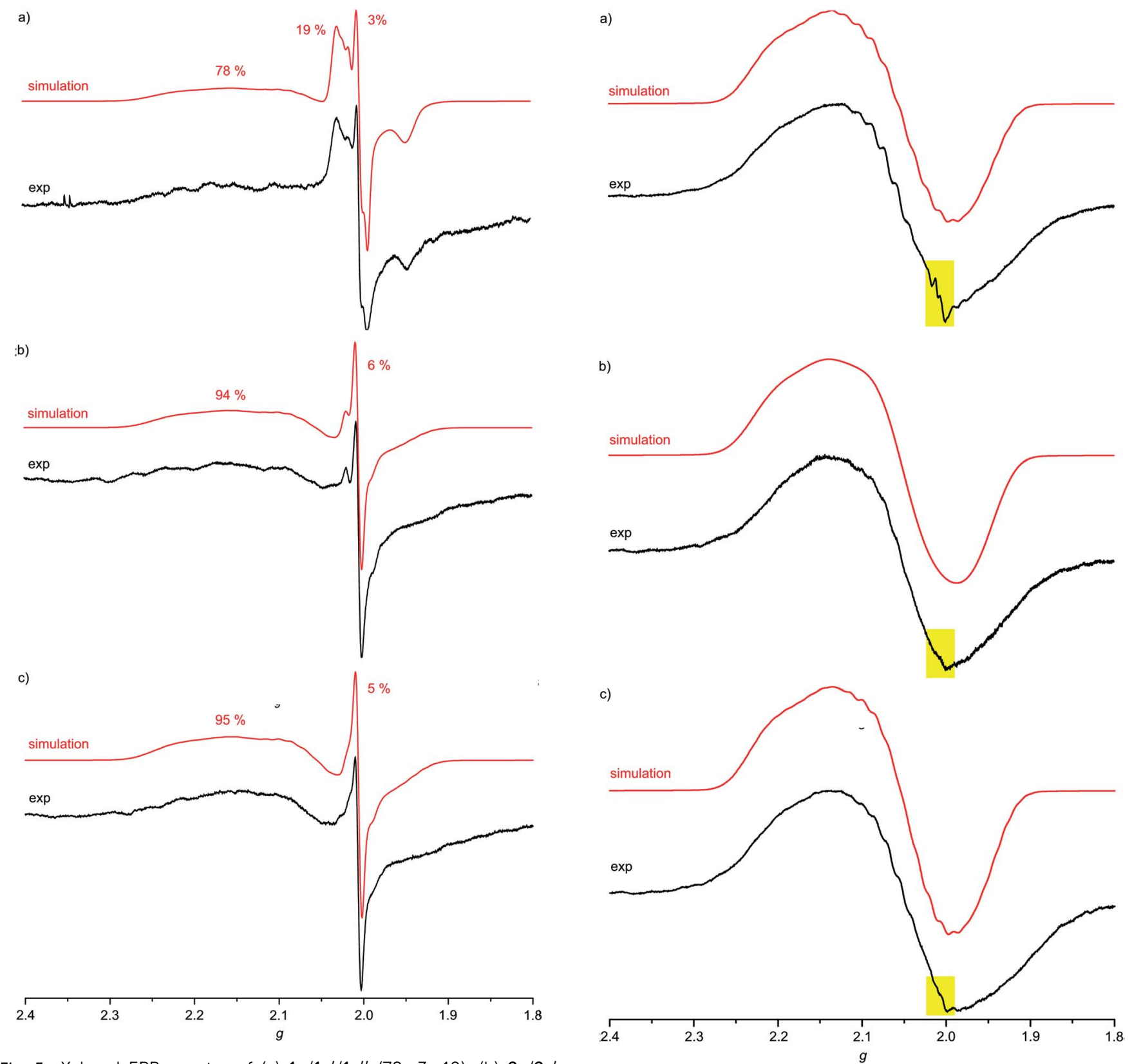

Fig. $5 \mathrm{X}$-band EPR spectra of (a) $1 \mathrm{a} / 1 \mathrm{a}^{\prime} / 1 \mathrm{a}^{\prime \prime}$ (78:3:19), (b) $2 \mathrm{a} / 2 \mathrm{a}^{\prime}$ (94: 6) and (c) 3a/3a' (95:5) in frozen $\mathrm{CH}_{2} \mathrm{Cl}_{2}$ solution $(77 \mathrm{~K}, 9.4 \mathrm{GHz}$ ) and corresponding simulations.

Fig. 7 and $\mathrm{ESI}_{\dagger}$ ). The most significant differences between the cationic gold(III) complexes and their neutral congeners are found in the $\mathrm{Au}-\mathrm{N}$ distances which increase by $c a$. $4 \%$ from 2.051 to $2.124 \AA$ in all cases (Table 3 ). The large changes of the $\mathrm{Au}-\mathrm{N}$ distances (Table 3) contribute to the reorganisation energy of the reduction process. ${ }^{13 c}$ The gold ions are located nearly perfectly in the centre of the four pyrrolic nitrogen atoms in all complexes. The macrocycle itself displays only minor distortions both in the cations as well as in the neutral complexes. A minor increase of the saddling $\left(B_{2 \mathrm{u}}\right)$ distortion is noted in the neutral complexes (Table 3 ). These metrical data of 1a-4c strongly suggest that the reduction of the metal centre to $\mathrm{Au}^{\mathrm{II}}$ is favoured in the electronic ground state. A reduction of

Fig. 6 X-band EPR spectra of (a) $4 a(\mathrm{MeOH})$, (b) $4 \mathrm{~b}$ (THF) and (c) 4c (THF) in frozen solution ( $77 \mathrm{~K}, 9.4 \mathrm{GHz}$ ) and corresponding simulations; yellow squares highlight the presence of traces of porphyrin radical anions $4 a^{\prime}, 4 b^{\prime}$ and $4 c^{\prime}$, respectively.

the porphyrin to its radical anion $1 \mathbf{a}^{\prime}-\mathbf{4} \mathbf{c}^{\prime}$ should result in pronounced macrocycle distortions as well as in small $\mathrm{Au}^{\mathrm{III}}-\mathrm{N}$ (radical anion) bond distances which is not observed. The calculated Mulliken spin densities are in full accordance with these structural parameters. In all neutral complexes the majority of the spin density is located at the metal centre (Mulliken spin density at Au: 0.44), especially in the $5 \mathrm{~d}_{x^{2}-y^{2}}$ orbital (Fig. 7 and ESI $\dagger$ ). The remainder is distributed over the pyrrolic nitrogen atoms in the $\sigma$-orbitals pointing towards the metal centre (Mulliken spin density at N: 0.14). This clearly advocates a gold-centred radical localised in the $\sigma$-system of the 
Table 3 Metrical data of DFT optimised porphyrinato gold(III) complexes and their one-electron reduced counterparts

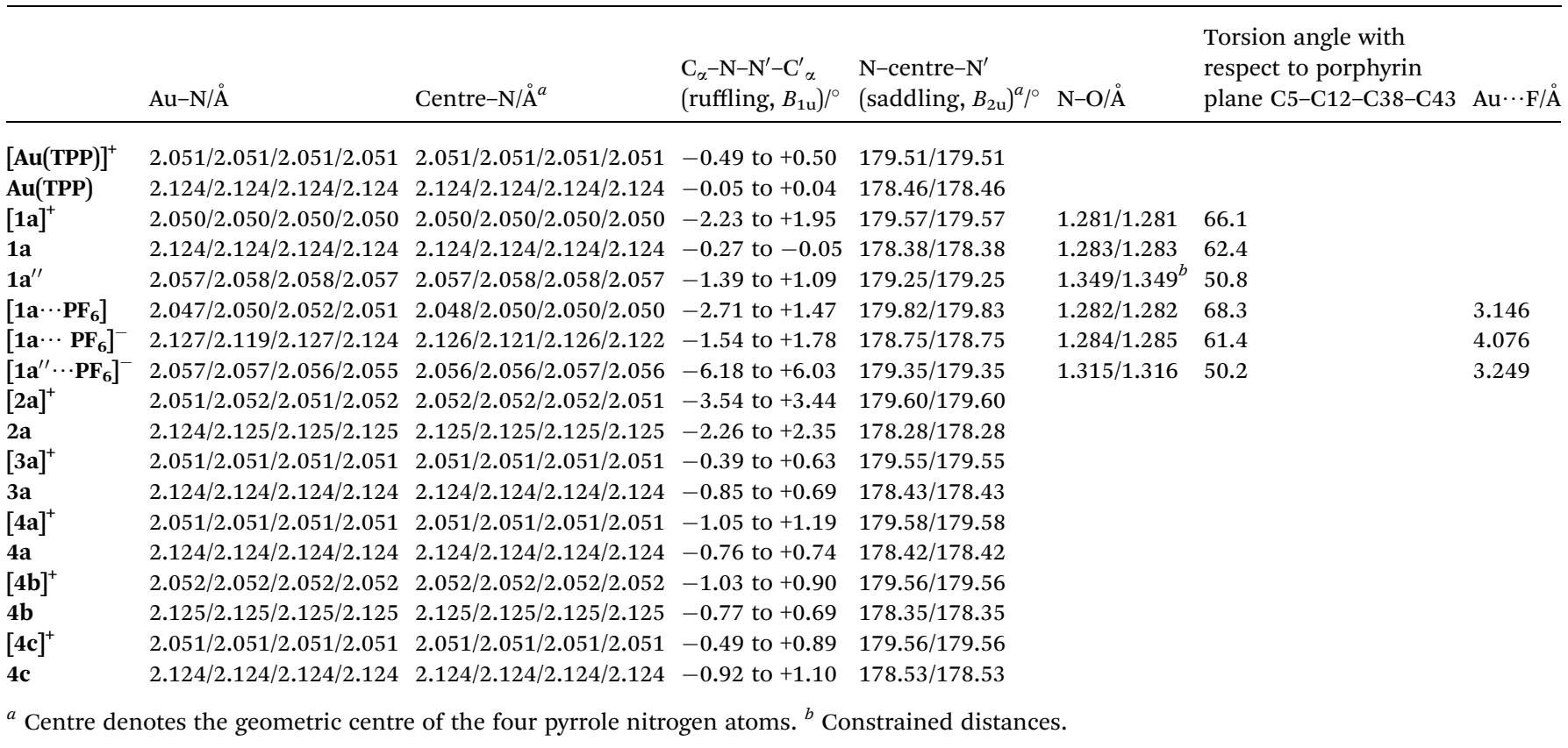

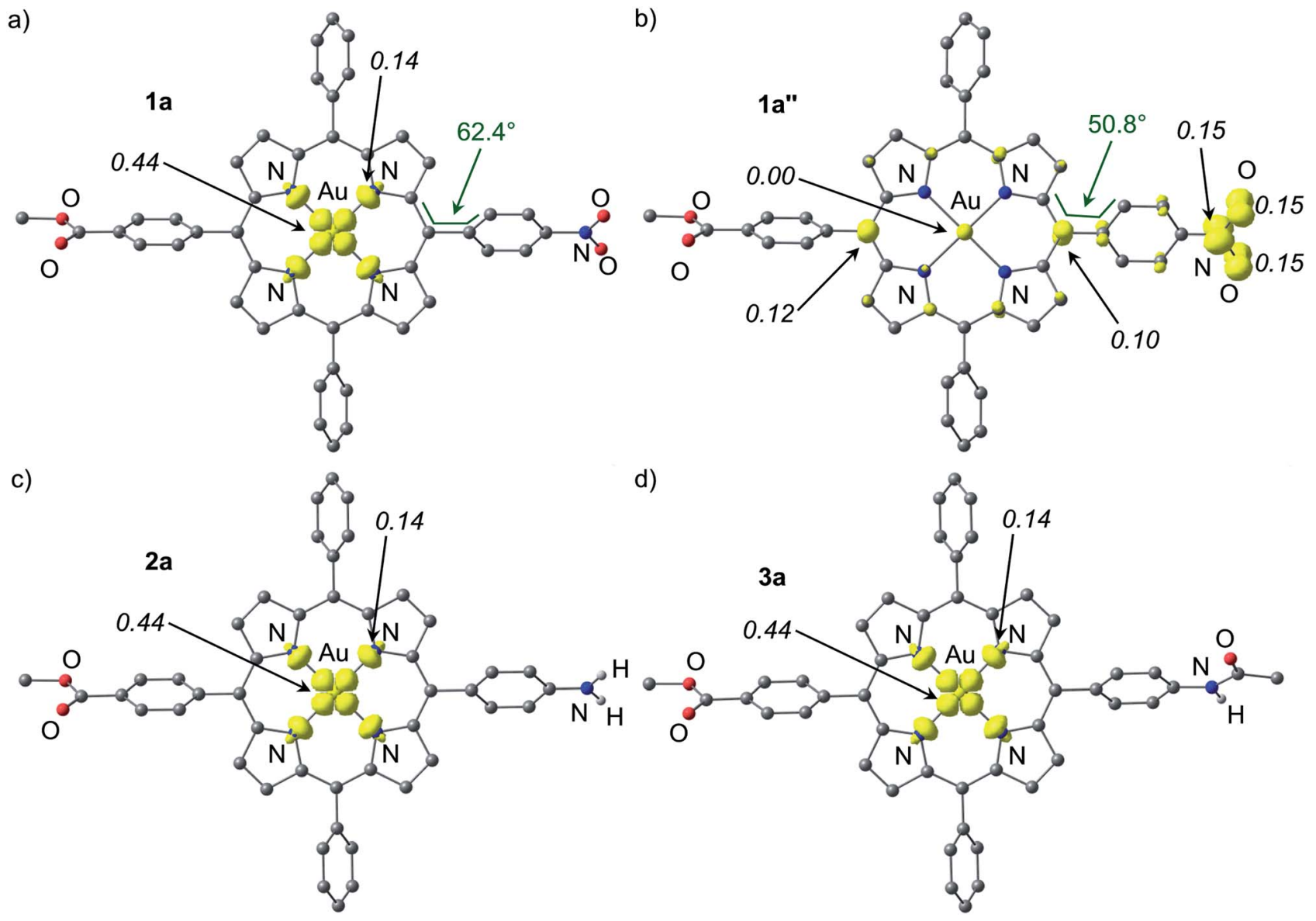

Fig. 7 Spin densities of DFT optimised geometries of (a) 1a, (b) 1a" (constrained), (c) 2a and (d) 3a (isosurface value at 0.01 a.u. in yellow; 0.006 a.u. for 1a"; UB3LYP, LANL2DZ, IEFPCM CH $\mathrm{CH}_{2} \mathrm{Cl}_{2} ; \mathrm{CH}$ hydrogen atoms omitted; Mulliken spin densities in italics). 
almost planar molecule rather than a porphyrin radical anion with the spin delocalised in the $\pi$-system of the porphyrin. The DFT determined $\mathrm{Au}^{\mathrm{II}}$ electronic ground states of $\mathbf{1 a}-\mathbf{4 c}$ perfectly match the experimentally derived ground states. The spin densities are also in full agreement with experimentally determined EPR parameters ( $g$ values, ${ }^{197} \mathrm{Au}$ hyperfine coupling and ${ }^{14} \mathrm{~N}$ superhyperfine coupling). Compared with the isoelectronic Cu(TPP) [Mulliken spin density at $\mathrm{Cu}$ : 0.58; Mulliken spin density at N: 0.105$]$ the spin densities are more delocalised onto the nitrogen atoms which is in agreement with the EPR results as well $(\mathrm{ESI} \dagger){ }^{17 d}$

The special case of the nitro derivative 1a which displays significant amounts of the nitrobenzene $\pi$ radical anion valence isomer $\mathbf{1 a}^{\prime \prime}$ in the EPR spectrum (Fig. 5a) was treated by DFT methods as well. However, all geometry optimisation attempts (with the employed functional, basis set and tight convergence criteria) converged to the stable $\mathrm{Au}^{\mathrm{II}}$ valence isomer 1a. In order to get an impression on the spin density distribution in valence isomer $\mathbf{1 a}^{\prime \prime}$, the nitrobenzene radical anion $\left[\mathrm{C}_{6} \mathrm{H}_{5} \mathrm{NO}_{2}\right]^{\cdot-}$ was separately optimised by DFT methods giving NO distances of $1.349 \AA$ A. These NO distances were then constrained to $1.349 \AA$ in geometry optimizations of $\mathbf{1 a}^{\prime \prime}$ giving the (constrained) optimised structure of $1 \mathbf{a}^{\prime \prime}$ as shown in Fig. 7. The Au-N bond lengths of $\mathbf{1 a}^{\prime \prime}$ are fully consistent with a gold(III) oxidation state (Table 3). Compared to [1a $]^{+}$and $\mathbf{1 a}$ the $\mathrm{C}_{6} \mathrm{H}_{4} \mathrm{NO}_{2}$ torsion angle with respect to the porphyrin plane $\mathrm{C} 5-\mathrm{C} 12-\mathrm{C} 38-\mathrm{C} 43$ is significantly reduced from $66.1^{\circ}$ and $62.4^{\circ}$ to $50.8^{\circ}$ suggesting

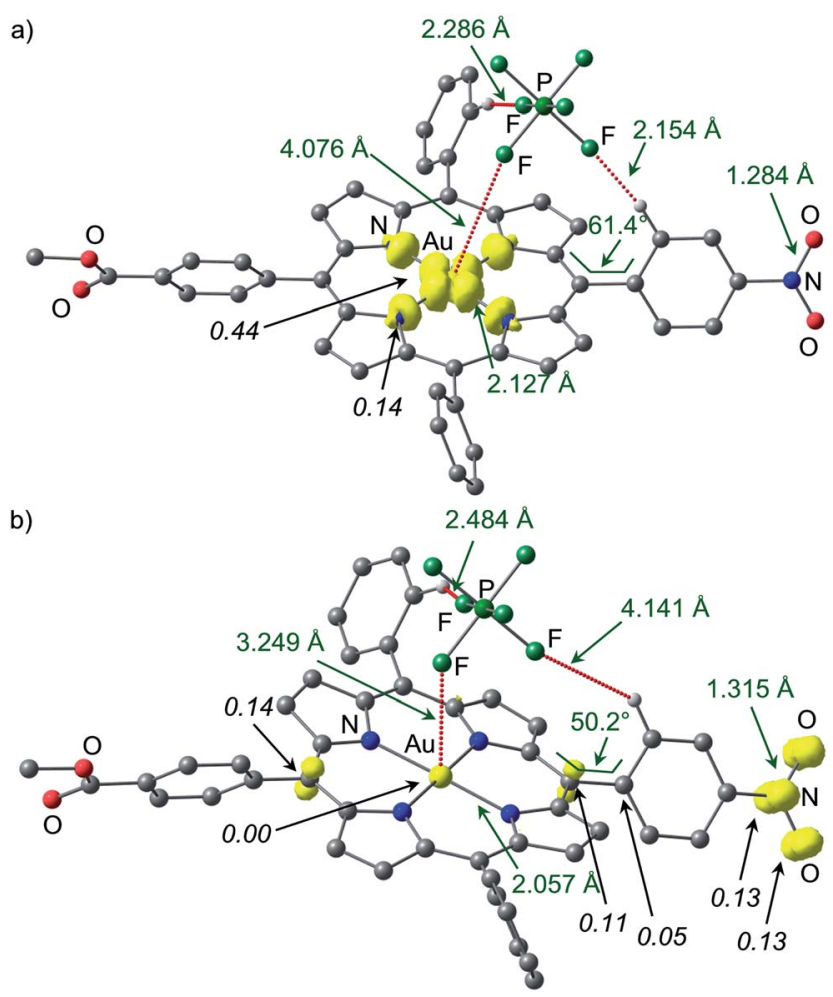

Fig. 8 Spin densities of DFT optimised geometries of (a) $\left[1 \mathrm{a} \cdots \mathrm{PF}_{6}\right]^{-}$ and (b) $\left[1 \mathrm{a}^{\prime \prime} \ldots \mathrm{PF}_{6}\right]^{-}$(isosurface value at 0.01 a.u. in yellow; UB3LYP, LANL2DZ, IEFPCM CH $\mathrm{Cl}_{2} \mathrm{Cl}_{2}$; hydrogen atoms which are not involved in hydrogen bonds are omitted; Mulliken spin densities in italics). a conjugative electron withdrawing effect of the gold(III) porphyrin as expected for a $\pi$-centred radical. The spin density is mainly located at the $\mathrm{NO}_{2}$ substituent and partially delocalised over the $\pi$-system of the porphyrin. The Mulliken spin density at the gold atom in $\mathbf{1 a}^{\prime \prime}$ is essentially zero (Fig. 7).

As an unconstrained optimization of $\mathbf{1 a}^{\prime \prime}$ was unsuccessful, we investigated the effect of the counterion $\left[\mathrm{PF}_{6}\right]^{-}$on the charge and spin distribution in $\left[\mathbf{1} \mathbf{a} \cdots \mathbf{P F}_{\mathbf{6}}\right]^{-}$and $\left[\mathbf{1 a}^{\prime \prime} \cdots \mathbf{P F}_{\mathbf{6}}\right]^{-}$, respectively. Indeed, we succeeded in optimising both valence isomers $\left[\mathbf{1} \mathbf{a} \cdots \mathbf{P F}_{\mathbf{6}}\right]^{-}$and $\left[\mathbf{1 a}^{\prime \prime} \cdots \mathbf{P F}_{\mathbf{6}}\right]^{-}$without any constraints (Fig. 8). The $\mathrm{Au}^{\mathrm{II}}$ valence isomer $\left[\mathbf{1} \mathbf{a} \cdots \mathbf{P F}_{\mathbf{6}}\right]^{-}$is preferred by $12 \mathrm{~kJ} \mathrm{~mol}^{-1}$. In this $\mathrm{Au}^{\mathrm{II}}$ isomer $\left[\mathbf{1 a} \cdots \mathbf{P F}_{\mathbf{6}}\right]^{-}$the $\left[\mathrm{PF}_{6}\right]^{-}$ion is not coordinated to the metal $(\mathrm{Au} \cdots \mathrm{F} 4.076 \AA$ ) but only hydrogen-bonded to two $\mathrm{CH}$ groups of the aryl substituents (Fig. 8a). The spin density is again localised at the metal centre (Mulliken spin density at Au: 0.44 ) and the pyrrolic nitrogen atoms (Mulliken spin density at $\mathrm{N}: 0.14)$. In the nitro-based $\pi$ radical $\left[\mathbf{1 a}^{\prime \prime} \cdots \mathbf{P F}_{\mathbf{6}}\right]^{-}$the $\left[\mathrm{PF}_{6}\right]^{-}$ion is much closer to the gold centre (Au $\cdots$ F $3.249 \AA$, Fig. 8b). The presence of the negative charge close to the metal centre stabilises the $\mathrm{Au}^{\mathrm{III}}$ oxidation state and indeed the gold ion carries no spin density. Au-N distances $\left(2.057 \AA\right.$; $\left.\left[\mathbf{1 a}^{\prime \prime} \cdots \mathbf{P F}_{\mathbf{6}}\right]^{-}\right)$fully agree with a gold(III) porphyrin but not with a gold(II) porphyrin

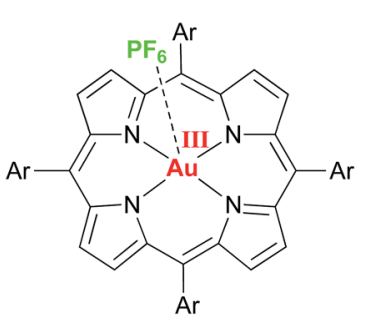

$[1 \mathrm{a}]\left(\mathrm{PF}_{6}\right)-[4 \mathrm{c}]\left(\mathrm{PF}_{6}\right)$<smiles>C[13CH2][13CH3]</smiles>

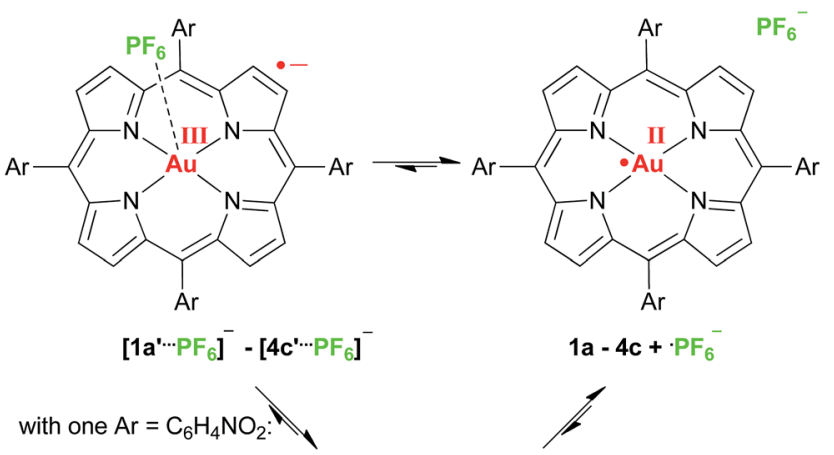

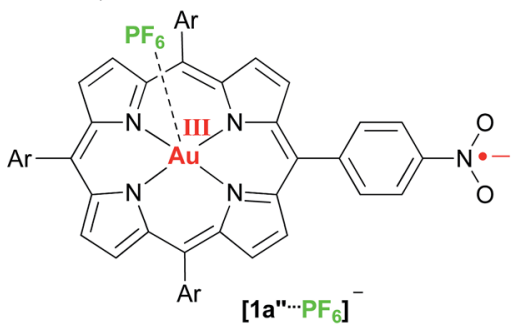

Scheme 3 Valence tautomeric equilibria of gold(॥) porphyrins and gold(III) porphyrin radical anions. 
$\left(2.127 \AA ;\left[\mathbf{1 a} \cdots \mathbf{P F}_{\mathbf{6}}\right]^{-}\right)$. The $\mathrm{N}-\mathrm{O}$ distances have increased from $1.284 \AA$ in $\left[\mathbf{1} \mathbf{a} \cdots \mathbf{P F}_{\mathbf{6}}\right]^{-}$to $1.315 \AA$ in $\left[\mathbf{1 a}^{\prime \prime} \cdots \mathbf{P F}_{\mathbf{6}}\right]^{-}$as expected for population of $\mathrm{N}-\mathrm{O}$ antibonding orbitals. The spin density is largely confined to the $\mathrm{NO}_{2}$ substituent and partially delocalized to the $\pi$-system of the porphyrin. The C5-C12-C38-C43 torsion angle of the nitrophenyl substituent decreases from $61.4^{\circ}([1 \mathrm{a} \cdots$ $\left.\left.\mathbf{P F}_{\mathbf{6}}\right]^{-}\right)$to $50.2^{\circ}\left(\left[\mathbf{1 a}^{\prime \prime} \cdots \mathbf{P F}_{\mathbf{6}}\right]^{-}\right)$similar to the $\mathbf{1 a} / \mathbf{1} \mathbf{a}^{\prime \prime}$ (constrained) pair. In essence, the intramolecular electron transfer pathway between $\left[\mathbf{1} \mathbf{a} \cdots \mathbf{P F}_{\mathbf{6}}\right]^{-}$and $\left[\mathbf{1 a}^{\prime \prime} \cdots \mathbf{P F}_{\mathbf{6}}\right]^{-}$encompasses the $\mathrm{Au}-\mathrm{N}$ and $\mathrm{Au} \cdots \mathrm{F}$ distances (totally symmetric stretching vibration of the gold coordination sphere), the symmetric $\mathrm{NO}_{2}$ stretching mode and a phenyl torsional motion (Fig. 8).

With respect to photoinduced electron transfer reactions using porphyrinato gold(III) complexes as electron acceptors we suggest that the initial kinetic reduction product of a porphyrinato gold(III) complex should be a gold(III) porphyrin $\pi$ radical anion (such as $\mathbf{1} \mathbf{a}^{\prime}-\mathbf{4} \mathbf{c}^{\prime}$ ) due to the smaller activation barrier and the better electronic coupling to electron donors (Scheme 3). In a following intramolecular valence isomerisation the electron shifts to the central gold ion ( $\sigma$-system) with concomitant dissociation of the counterion giving the thermodynamic $\mathrm{Au}^{\mathrm{II}}$ product (such as 1a-4c) (Scheme 3). The latter chemical reaction will render the whole photoinduced ET process irreversible, which is advantageous for further reactivity of the redox sites. In the case of nitro substituted porphyrins a further valence isomer $\left[\mathbf{1 a}^{\prime \prime} \cdots \mathbf{P F}_{\mathbf{6}}\right]^{-}$with a nitrophenyl $\pi$ radical anion is existent as well. Both the solvent, the present ions and the substituents determine the final charge and spin distribution.

\section{Experimental}

Porphyrins $\mathrm{H}_{2}$ TPP, Ia, IIa, IIIa, IVa, IVb and IVc were prepared according to published procedures. ${ }^{17}$ Solvents were dried by standard methods. Other reagents were used as received from commercial suppliers (Acros, Sigma-Aldrich). NMR spectra were recorded on a Bruker Avance DRX 400 spectrometer at 400.31 MHz $\left({ }^{1} \mathrm{H}\right), 100.05 \mathrm{MHz}\left({ }^{13} \mathrm{C}\left\{{ }^{1} \mathrm{H}\right\}\right), 162.05 \mathrm{MHz}\left({ }^{31} \mathrm{P}\left\{{ }^{1} \mathrm{H}\right\}\right)$. Resonances are reported in $\mathrm{ppm}$ versus the solvent signal as an internal standard. $\mathrm{CD}_{2} \mathrm{Cl}_{2}\left({ }^{1} \mathrm{H}: \delta=5.32 \mathrm{ppm} ;{ }^{13} \mathrm{C}: \delta=53.8 \mathrm{ppm}\right)$, $\mathrm{d}_{8}$-THF $\left({ }^{1} \mathrm{H}: \delta=1.73,3.58 \mathrm{ppm} ;{ }^{13} \mathrm{C}: \delta=25.5,67.7 \mathrm{ppm}\right) \mathrm{MeOD}$ $\left({ }^{1} \mathrm{H}: \delta=3.31,4.87 \mathrm{ppm} ;{ }^{13} \mathrm{C}: \delta=49.0 \mathrm{ppm}\right)$ and versus external $\mathrm{H}_{3} \mathrm{PO}_{4}(85 \%)\left({ }^{31} \mathrm{P}: \delta=0 \mathrm{ppm}\right) ;(\mathrm{s})=$ singlet, $(\mathrm{pt})=$ pseudo triplet (unresolved doublet of doublets), (br, s) = broad singlet, septet (sept). IR spectra were recorded with a BioRad Excalibur FTS 3100 spectrometer as $\mathrm{KBr}$ disks; (vs) = very strong, (s) = strong, $(\mathrm{m})=$ medium,$(\mathrm{w})=$ weak. ESI mass spectra were recorded on a Micromass Q-TOF-Ultima spectrometer. Electrochemical experiments were carried out on a BioLogic SP-50 voltammetric analyzer using a glassy carbon working electrode, a platinum wire as the counter electrode and a $0.01 \mathrm{M} \mathrm{Ag} / \mathrm{AgNO}_{3}$ electrode as the reference electrode. The measurements were carried out at a scan rate of $100 \mathrm{mV} \mathrm{s}^{-1}$ for cyclic voltammetry experiments and for square wave voltammetry experiments using a concentration of $10^{-3} \mathrm{M}$ in $0.1 \mathrm{M}\left[{ }^{n} \mathrm{Bu}_{4} \mathrm{~N}\right]\left[\mathrm{PF}_{6}\right]$ as the supporting electrolyte in THF $(\mathrm{MeOH})$. Potentials are given relative to the ferrocene/ferrocenium couple. Spectroelectrochemical experiments were performed using a thin layer quartz glass (path length $1 \mathrm{~mm}$ ) cell kit (GAMEC Analysentechnik, Illingen, Germany) equipped with a Pt gauze working electrode, a Pt counter electrode and a $\mathrm{Ag} / \mathrm{AgNO}_{3}$ reference electrode $\left(10^{-5} \mathrm{M}\right.$ solutions in THF or in $\mathrm{MeOH}$, containing 0.1 $\left.\mathrm{M}\left[{ }^{n} \mathrm{Bu}_{4} \mathrm{~N}\right]\left[\mathrm{PF}_{6}\right]\right)$. X-band $\mathrm{CW}$ EPR spectra were measured on a Miniscope MS 300 (Magnettech $\mathrm{GmbH}$, Germany). $g$-Values are referenced to external $\mathrm{Mn}^{2+}$ in $\mathrm{ZnS}(g=2.118,2.066,2.027,1.986,1.946,1.906)$. Simulations were performed with the program package EasySpin. ${ }^{24} \mathrm{UV} / \mathrm{Vis} /$ NIR spectra were recorded on a Varian Cary 5000 spectrometer using $1.0 \mathrm{~cm}$ cells (Hellma, suprasil).

\section{DFT calculations}

Density functional calculations were carried out with the Gaussian09/DFT series ${ }^{25}$ of programs. The B3LYP formulation of density functional theory was used employing the LANL2DZ basis set. To include solvent effects the integral equation formalism polarisable continuum model (IEFPCM $\mathrm{CH}_{2} \mathrm{Cl}_{2}$ ) was employed. No (symmetry) constraints were imposed on the molecules, except for the NO distance constraint for $\mathbf{1 a}^{\prime}$. The presence of energy minima of the ground states was checked by analytical frequency calculations.

\section{EPR measurements of radical anions}

Under an inert atmosphere a solution of the respective gold(III) porphyrin complex $\left(c=5 \times 10^{-3} \mathrm{M}\right)$ in $\mathrm{CH}_{2} \mathrm{Cl}_{2}\left([\mathbf{A u}(\mathbf{T P P})]\left[\mathbf{P F}_{\mathbf{6}}\right]\right.$, $\left.[\mathbf{1} \mathbf{a}]\left[\mathbf{P F}_{\mathbf{6}}\right],[\mathbf{2 a}]\left[\mathbf{P F}_{\mathbf{6}}\right],[\mathbf{3 a}]\left[\mathbf{P F}_{\mathbf{6}}\right]\right), \mathrm{MeOH}\left([\mathbf{4 a}]\left[\mathbf{P F}_{\mathbf{6}}\right]\right)$ or THF $([\mathbf{4 b}]$ $\left.\left[\mathbf{P F}_{\mathbf{6}}\right],[\mathbf{4} \mathbf{c}]\left[\mathbf{P F}_{\mathbf{6}}\right]\right)$ was treated with 0.95 equivalents of cobaltocene $\mathrm{CoCp}_{2}$. The X-band EPR spectrum of the sample was measured immediately after freezing the solution to $77 \mathrm{~K}$. The effect of chloride was measured by addition of 2.0 equivalents of $\left[{ }^{n} \mathrm{Bu}_{4} \mathrm{~N}\right] \mathrm{Cl}$ prior to the reduction.

\section{$[5,10,15,20$-Tetraphenylporphyrinato $]$ gold(III) hexafluorophosphate $[\mathrm{Au}(\mathrm{TPP})]\left[\mathrm{PF}_{6}\right]$}

5,10,15,20-Tetraphenylporphyrin (50 mg, $0.08 \mathrm{mmol}$ ), potassium tetrachloridoaurate(III) (121 $\mathrm{mg}, 0.32 \mathrm{mmol}$ ) and sodium acetate $(302 \mathrm{mg}, 3.68 \mathrm{mmol})$ were dissolved in glacial acetic acid $(20 \mathrm{~mL})$. The reaction mixture was heated to reflux for $20 \mathrm{~h}$, allowed to cool to room temperature, and diluted with dichloromethane $(100 \mathrm{~mL})$. The mixture was washed with water $(2 \times 50 \mathrm{~mL})$, saturated sodium carbonate solution $(2 \times 50 \mathrm{~mL})$ and water $(1 \times 50 \mathrm{~mL})$, dried over anhydrous magnesium sulfate and filtered. The filtrate was evaporated to dryness and the residue dissolved in dichloromethane $(50 \mathrm{~mL})$. The organic phase was stirred with a saturated aqueous solution of potassium hexafluorophosphate $(10 \mathrm{~mL})$ for $72 \mathrm{~h}$. The mixture was diluted with dichloromethane $(100 \mathrm{~mL})$ and washed with water $(2 \times 50 \mathrm{~mL})$, dried over anhydrous magnesium sulfate, and filtered. The filtrate was removed under reduced pressure and the residue purified by chromatography over silica [dichloromethane : methanol (20:1); $\left.R_{\mathrm{f}}=0.40\right]$ to yield $[\mathbf{A u}(\mathbf{T P P})]\left[\mathbf{P F}_{\mathbf{6}}\right]$ (66 mg, $0.09 \mathrm{mmol}, 88 \%$ ) as a purple crystalline solid. $\mathrm{C}_{44} \mathrm{H}_{28^{-}}$ $\mathrm{AuF}_{6} \mathrm{~N}_{4} \mathrm{P}$ (954.7). UV/Vis: $\lambda_{\max }(\mathrm{THF}) / \mathrm{nm} 409 \quad\left(\varepsilon / \mathrm{M}^{-1} \mathrm{~cm}^{-1}\right.$ 258 000), 523 (12 400). IR: $\nu_{\max } / \mathrm{cm}^{-1} 1638(\mathrm{~m}), 1617$ (s), 839 (vs, $\mathrm{PF}), 556$ (m, PF 6 ,def $)$. NMR: $\delta_{\mathrm{H}}\left(400 \mathrm{MHz}, \mathrm{CD}_{2} \mathrm{Cl}_{2}\right) 7.93(12 \mathrm{H}, \mathrm{m}$, $\left.\mathrm{H}^{5 / 5 / 10 / 10 / 15 / 15 / 20 / 20}{ }_{3 / 4 / 3 / 4 / 3 / 4 / 3 / 4}\right), 8.24$ (8H, m, $\mathrm{H}_{2 / 2 / 2 / 2}^{5 / 10 / 15 / 20}$, 
$9.36\left(8 \mathrm{H}, \mathrm{s}, \mathrm{H}^{2,3,7,8,12,13,17,18}\right) ; \delta_{\mathrm{C}}\left(100 \mathrm{MHz}, \mathrm{CD}_{2} \mathrm{Cl}_{2}\right) 124.1$ $\left(\mathrm{s}, \mathrm{C}^{5 / 10 / 15 / 20}\right), 128.1\left(\mathrm{~s}, \mathrm{C}^{5 / 10 / 15 / 20}{ }_{3 / 3 / 3 / 3}\right), 129.8\left(\mathrm{~s}, \mathrm{C}_{4 / 4 / 4 / 4}^{5 / 10 / 15 / 20}\right)$, $132.7\left(\mathrm{~s}, \mathrm{C}^{2 / 3 / 7 / 8 / 12 / 13 / 17 / 18}\right), 134.5\left(\mathrm{~s}, \mathrm{C}^{5 / 10 / 15 / 20}{ }_{2 / 2 / 2 / 2}\right), 137.3$ $\left(\mathrm{s}, \mathrm{C}^{1 / 4 / 6 / 9 / 11 / 14 / 16 / 19}\right), 138.7\left(\mathrm{~s}, \mathrm{C}^{5 / 10 / 15 / 20}{ }_{1 / 1 / 1 / 1}\right) \cdot \delta_{\mathrm{P}}(162 \mathrm{MHz}$, $\mathrm{CD}_{2} \mathrm{Cl}_{2}$ ) -143.8 (sept, ${ }^{1} J_{\mathrm{PF}}=710 \mathrm{~Hz}$ ). MS (ESI): $\mathrm{m} / z 809.99$ (100\%) $[\mathrm{M}]^{+}$. HR-MS (ESI): $m / z 809.1993$ (calcd for $\mathrm{C}_{44} \mathrm{H}_{28} \mathrm{AuN}_{4}$ : 809.1980). CV (Fc/Fc $\left.{ }^{+}, \mathrm{THF}\right): E_{\frac{1}{2}} / \mathrm{V}-2.350,-1.650,-0.975$.

[10,20-Di(phenyl)-15-(4-(methoxycarbonylphenyl))-5-(4nitrophenyl)porphyrinato]gold(III) hexafluorophosphate [1a] [PF 6

10,20-Di(phenyl)-15-(4-(methoxycarbonylphenyl))-5-(4-nitrophenyl)porphyrin Ia $(100 \mathrm{mg}, 0.14 \mathrm{mmol})$, potassium tetrachloridoaurate(III) (212 $\mathrm{mg}, 0.56 \mathrm{mmol})$ and sodium acetate (529 $\mathrm{mg}, 6.44 \mathrm{mmol})$ were dissolved in glacial acetic acid $(40 \mathrm{~mL})$. The reaction mixture was heated to reflux for $22 \mathrm{~h}$, allowed to cool to room temperature, and diluted with dichloromethane $(200 \mathrm{~mL})$. The mixture was washed with water $(2 \times 100 \mathrm{~mL})$, saturated aqueous sodium carbonate solution $(2 \times 100 \mathrm{~mL})$ and water $(1 \times 100 \mathrm{~mL})$, dried over anhydrous magnesium sulfate and filtered. The filtrate was evaporated to dryness and the residue dissolved in dichloromethane $(100 \mathrm{~mL})$. The organic phase was stirred with a saturated aqueous solution of potassium hexafluorophosphate $(20 \mathrm{~mL})$ for $72 \mathrm{~h}$. The mixture was diluted with dichloromethane $(100 \mathrm{~mL})$ and washed with water $(2 \times 50 \mathrm{~mL})$, dried over anhydrous magnesium sulfate, and filtered. The filtrate was removed under reduced pressure and the residue purified by chromatography over silica [dichloromethane : methanol $\left.(10: 1) ; R_{\mathrm{f}}=0.35\right]$ to yield $[\mathbf{1 a}]\left[\mathbf{P F}_{\mathbf{6}}\right]$ (64 $\mathrm{mg}, 0.06 \mathrm{mmol}, 43 \%$ ) as a purple crystalline solid. $\mathrm{C}_{46} \mathrm{H}_{29^{-}}$ $\mathrm{AuF}_{6} \mathrm{~N}_{5} \mathrm{O}_{4} \mathrm{P}$ (1057.7). UV/Vis: $\lambda_{\max }(\mathrm{THF}) / \mathrm{nm} 410\left(\varepsilon / \mathrm{M}^{-1} \mathrm{~cm}^{-1}\right.$ 329 000), 523 (17 600). IR: $\nu_{\max } / \mathrm{cm}^{-1} 1717$ (s, CO $\mathrm{Cster}_{\text {), }} 1597(\mathrm{~m})$, 1520 (s, NO asym $\left._{1}\right), 1439$ (m), 1346 (s, NO sym $\left._{\text {sy }}\right), 1277$ (s, OCO def $), 1106$ (m), 1034 (s), 1018 (s), 837 (vs, PF), 556 (s, PF 6 ,def). NMR: $\delta_{\mathrm{H}}(400$ $\left.\mathrm{MHz}, \mathrm{CD}_{2} \mathrm{Cl}_{2}\right) 4.12\left(3 \mathrm{H}, \mathrm{s}, \mathrm{H}^{15}{ }_{6}\right), 7.95\left(6 \mathrm{H}, \mathrm{m}, \mathrm{H}^{10 / 10 / 20 / 20}{ }_{3 / 3 / 4 / 4}\right)$, $8.29\left(4 \mathrm{H}, \mathrm{d}, \mathrm{H}_{2 / 2}{ }^{10 / 20}\right), 8.39\left(2 \mathrm{H}, \mathrm{d},{ }^{3} J_{\mathrm{HH}}=8.2 \mathrm{~Hz}, \mathrm{H}^{15}{ }_{2}\right), 8.50$ $\left(2 \mathrm{H}, \mathrm{d},{ }^{3} J_{\mathrm{HH}}=8.5 \mathrm{~Hz}, \mathrm{H}^{5}{ }_{2}\right), 8.57\left(2 \mathrm{H}, \mathrm{d},{ }^{3} J_{\mathrm{HH}}=8.1 \mathrm{~Hz}, \mathrm{H}^{15}{ }_{3}\right)$, $8.75\left(2 \mathrm{H}, \mathrm{d},{ }^{3} J_{\mathrm{HH}}=8.5 \mathrm{~Hz}, \mathrm{H}^{5}{ }_{3}\right), 9.35\left(8 \mathrm{H}, \mathrm{m}, \mathrm{H}^{2,3,7,8,12,13,17,18}\right)$; $\delta_{\mathrm{C}}\left(100 \mathrm{MHz}, \mathrm{CD}_{2} \mathrm{Cl}_{2}\right) 52.5\left(\mathrm{~s}, \mathrm{C}^{15}{ }_{6}\right), 121.4\left(\mathrm{~s}, \mathrm{C}^{15}\right), 123.4\left(\mathrm{~s}, \mathrm{C}_{3}^{5}\right)$, $124.8\left(\mathrm{~s}, \mathrm{C}^{10 / 20}\right), 128.4\left(\mathrm{~s}, \mathrm{C}^{10 / 20}{ }_{3 / 3}\right), 129.4\left(\mathrm{~s}, \mathrm{C}^{15}{ }_{3}\right), 130.0(\mathrm{~s}$, $\left.\mathrm{C}_{4 / 4}^{10 / 20}\right), 132.2\left(\mathrm{~s}, \mathrm{C}_{4}^{15}\right), 132.8-133.7$ (multiple $\mathrm{s}, \mathrm{C}^{2 / 3 / 7 / 8 / 12 / 13 / 17 / 18}$ ), $134.8\left(\mathrm{~s}, \mathrm{C}^{10 / 20 / 15}{ }_{2 / 2 / 2}\right.$ ), $136.5\left(\mathrm{~s}, \mathrm{C}_{2}^{5}\right.$ ), 136.9-138.0 (multiple $\mathrm{s}$, $\left.\mathrm{C}^{1 / 4 / 6 / 9 / 11 / 14 / 16 / 19}\right), 138.9\left(\mathrm{~s}, \mathrm{C}^{10 / 20}{ }_{1 / 1}\right), 143.3\left(\mathrm{~s}, \mathrm{C}^{15}{ }_{1}\right), 145.4(\mathrm{~s}$, $\left.\mathrm{C}^{5}{ }_{1}\right), 149.4\left(\mathrm{~s}, \mathrm{C}^{5}{ }_{4}\right), 167.1\left(\mathrm{~s}, \mathrm{C}^{15}{ }_{5}\right) . \delta_{\mathrm{P}}\left(162 \mathrm{MHz}, \mathrm{CD}_{2} \mathrm{Cl}_{2}\right)-144.1$ (sept, ${ }^{1} J_{\mathrm{PF}}=711 \mathrm{~Hz}$ ). MS (ESI): $m / z 912.11$ (100\%) [M] $]^{+}$. HR-MS (ESI): $m / z$ 912.1905 (calcd for $\mathrm{C}_{46} \mathrm{H}_{29} \mathrm{AuN}_{5} \mathrm{O}_{4}$ : 912.1885). CV (Fc/ $\left.\mathrm{Fc}^{+}, \mathrm{THF}\right): E_{\frac{1}{2}} / \mathrm{V}-2.300,-1.795,-1.560,-0.920$.

[5-(4-Aminophenyl)-10,20-di(phenyl)-15-(4(methoxycarbonylphenyl))porphyrinato]gold(III) hexafluorophosphate $[2 \mathrm{a}]\left[\mathbf{P F}_{6}\right]$

[10,20-Di(phenyl)-15-(4-(methoxycarbonylphenyl))-5-(4-nitrophenyl)porphyrinato]gold(III) hexafluorophosphate $[\mathbf{1 a}]\left[\mathbf{P F}_{\mathbf{6}}\right]$ (100 mg, $0.09 \mathrm{mmol}$ ) and tin(II) chloride dihydrate were suspended in concentrated hydrochloric acid $(36 \%, 50 \mathrm{~mL})$. The reaction mixture was stirred in the dark under argon for $20 \mathrm{~h}$.
The mixture was diluted with dichloromethane $(200 \mathrm{~mL})$, washed with water $(2 \times 100 \mathrm{~mL})$, saturated sodium carbonate solution $(2 \times 100 \mathrm{~mL})$, and water $(1 \times 100 \mathrm{~mL})$, dried over anhydrous magnesium sulfate and filtered. The filtrate was evaporated to dryness and the residue dissolved in dichloromethane $(100 \mathrm{~mL})$. The organic phase was stirred with a saturated aqueous solution of potassium hexafluorophosphate (20 $\mathrm{mL}$ ) for $72 \mathrm{~h}$. The mixture was diluted with dichloromethane $(100 \mathrm{~mL})$ and washed with water $(2 \times 50 \mathrm{~mL})$, dried over anhydrous magnesium sulfate and filtered. The filtrate was removed under reduced pressure and the residue purified by chromatography over silica [dichloromethane : methanol (25: 1); $\left.R_{\mathrm{f}}=0.22\right]$ to yield [2a] $\left[\mathbf{P F}_{6}\right](31 \mathrm{mg}, 0.03 \mathrm{mmol}, 34 \%)$ as a reddish-brown solid. $\mathrm{C}_{46} \mathrm{H}_{31} \mathrm{AuF}_{6} \mathrm{~N}_{5} \mathrm{O}_{2} \mathrm{P}$ (1027.7). UV/Vis: $\lambda_{\max }(\mathrm{THF}) / \mathrm{nm} 406\left(\varepsilon / \mathrm{M}^{-1} \mathrm{~cm}^{-1} 126000\right), 529$ (10 800), 589 (4800). IR: $\nu_{\max } / \mathrm{cm}^{-1} 1723$ (s, CO $\mathrm{Coster}$ ), 1638 (s), 1618 (vs, $\mathrm{NH}_{2, \mathrm{def}}$ ), 1277 (s, OCO ${ }_{\mathrm{def}}$ ), 966 (s), 835 (vs, PF), 567 (vs), 557 (s, PF 6 ,def). NMR: $\delta_{\mathrm{H}}\left(400 \mathrm{MHz}, \mathrm{CD}_{2} \mathrm{Cl}_{2}\right) 4.14\left(3 \mathrm{H}, \mathrm{s}, \mathrm{H}^{15}{ }_{6}\right), 4.7(2 \mathrm{H}$, br s, $\left.\mathrm{NH}_{2}\right), 7.25\left(2 \mathrm{H}, \mathrm{d},{ }^{3} J_{\mathrm{HH}}=8.3 \mathrm{~Hz}, \mathrm{H}_{3}^{5}\right), 7.95(6 \mathrm{H}, \mathrm{m}$, $\left.\mathrm{H}^{10 / 10 / 20 / 20}{ }_{3 / 4 / 3 / 4}\right), 8.03\left(2 \mathrm{H}, \mathrm{d},{ }^{3} J_{\mathrm{HH}}=8.4 \mathrm{~Hz}, \mathrm{H}^{5}{ }_{2}\right), 8.27(4 \mathrm{H}, \mathrm{m}$, $\left.\mathrm{H}^{10 / 20}{ }_{2 / 2}\right), 8.37\left(2 \mathrm{H}, \mathrm{d},{ }^{3} \mathrm{~J}_{\mathrm{HH}}=8.3 \mathrm{~Hz}, \mathrm{H}^{15}{ }_{2}\right), 8.57\left(2 \mathrm{H}, \mathrm{d},{ }^{3} J_{\mathrm{HH}}=\right.$ $\left.8.3 \mathrm{~Hz}, \mathrm{H}^{15}{ }_{3}\right), 9.40\left(8 \mathrm{H}, \mathrm{m}, \mathrm{H}^{2,3,7,8,12,13,17,18}\right) ; \delta_{\mathrm{C}}(100 \mathrm{MHz}$, $\left.\mathrm{CD}_{2} \mathrm{Cl}_{2}\right) 52.2\left(\mathrm{~s}, \mathrm{C}^{15}{ }_{6}\right), 114.6\left(\mathrm{~s}, \mathrm{C}^{5}{ }_{3}\right), 122.6\left(\mathrm{~s}, \mathrm{C}^{15}\right), 124.4(\mathrm{~s}$, $\left.\mathrm{C}^{10 / 20}\right), 127.5\left(\mathrm{~s}, \mathrm{C}^{5}\right), 128.4\left(\mathrm{~s}, \mathrm{C}^{10 / 20}{ }_{3 / 3}\right), 129.4\left(\mathrm{~s}, \mathrm{C}^{15}{ }_{3}\right), 130.2(\mathrm{~s}$, $\mathrm{C}^{10 / 20}{ }_{4 / 4}$ ), $132.3\left(\mathrm{~s}, \mathrm{C}^{15}{ }_{4}\right.$ ), 132.8-133.6 (multiple s, $\mathrm{C}^{2 / 3 / 7 / 8 / 12 / 13 / 17 / 18}$ ), $134.8\left(\mathrm{~s}, \mathrm{C}^{10 / 20 / 15}{ }_{2 / 2 / 2}\right), 135.6\left(\mathrm{~s}, \mathrm{C}^{5}{ }_{1}\right), 136.5\left(\mathrm{~s}, \mathrm{C}^{5}{ }_{2}\right), 137.1-137.7$ (multiple s, $\mathrm{C}^{1 / 4 / 6 / 9 / 11 / 14 / 16 / 19}$ ), $139.0\left(\mathrm{~s}, \mathrm{C}^{10 / 20}{ }_{1 / 1}\right), 143.5\left(\mathrm{~s}, \mathrm{C}^{15}{ }_{1}\right)$, $149.5\left(\mathrm{~s}, \mathrm{C}^{5}{ }_{4}\right), 167.2\left(\mathrm{~s}, \mathrm{C}^{15}{ }_{5}\right) . \delta_{\mathrm{P}}\left(162 \mathrm{MHz}, \mathrm{CD}_{2} \mathrm{Cl}_{2}\right)-143.5$ (sept, ${ }^{1} J_{\mathrm{PF}}=710 \mathrm{~Hz}$ ). MS (ESI): $m / z 882.09(100 \%)[\mathrm{M}]^{+}$. HR-MS (ESI): $\mathrm{m} / z$ 882.2163 (calcd for $\mathrm{C}_{46} \mathrm{H}_{31} \mathrm{AuN}_{5} \mathrm{O}_{2}$ : 882.2143). $\mathrm{CV}\left(\mathrm{Fc} / \mathrm{Fc}^{+}, \mathrm{THF}\right)$ : $E_{\frac{1}{2}} / \mathrm{V}-2.500$ (irrev.), $-2.280,-1.645,-0.990$.

\section{[5-(4-(N-Acetylaminophenyl))-10,20-di(phenyl)-15-(4- (methoxycarbonylphenyl))porphyrinato]gold(III) hexafluorophosphate $[3 a]\left[\mathrm{PF}_{6}\right]$}

5-(4-(N-Acetylaminophenyl))-10,20-di(phenyl)-15-(4-(methoxycarbonylphenyl))porphyrin IIIa (50 $\mathrm{mg}, 0.07 \mathrm{mmol})$, potassium tetrachloridoaurate(III) $(104 \mathrm{mg}, 0.28 \mathrm{mmol})$ and sodium acetate $(258 \mathrm{mg}, 3.15 \mathrm{mmol})$ were dissolved in glacial acetic acid $(20 \mathrm{~mL})$. The reaction mixture was heated to reflux for $24 \mathrm{~h}$, allowed to cool to room temperature, and diluted with dichloromethane $(100 \mathrm{~mL})$. The mixture was washed with water $(2 \times 50 \mathrm{~mL})$, saturated aqueous sodium carbonate solution $(2 \times 50 \mathrm{~mL})$ and water $(1 \times 50 \mathrm{~mL})$, dried over anhydrous magnesium sulfate and filtered. The filtrate was evaporated to dryness and the residue dissolved in dichloromethane $(50 \mathrm{~mL})$. The organic phase was stirred with a saturated aqueous solution of potassium hexafluorophosphate $(10 \mathrm{~mL})$ for $72 \mathrm{~h}$. The mixture was diluted with dichloromethane $(50 \mathrm{~mL})$ and washed with water (2 $\times 50 \mathrm{~mL}$ ), dried over anhydrous magnesium sulfate, and filtered. The filtrate was removed under reduced pressure and the residue purified by chromatography over silica [dichloromethane : methanol (10:1); $\left.R_{\mathrm{f}}=0.43\right]$ to yield [3a] $\left[\mathbf{P F}_{\mathbf{6}}\right]$ (32 $\mathrm{mg}, 0.03 \mathrm{mmol}, 49 \%$ ) as a purple crystalline solid. $\mathrm{C}_{48} \mathrm{H}_{33^{-}}$ $\mathrm{AuF}_{6} \mathrm{~N}_{5} \mathrm{O}_{3} \mathrm{P}$ (1069.7). UV/Vis: $\lambda_{\max }(\mathrm{THF}) / \mathrm{nm} 410\left(\varepsilon / \mathrm{M}^{-1} \mathrm{~cm}^{-1}\right.$ 124 000), 525 (10 500). IR: $\nu_{\max } / \mathrm{cm}^{-1} 2964$ (m, NH), 1717 (s, 
$\mathrm{CO}_{\text {ester }}$ ), 1677 (s, CO $\mathrm{Cmide}_{\text {ame }} 1616(\mathrm{~m}), 1262$ (s, OCO def $), 1096$ (s),

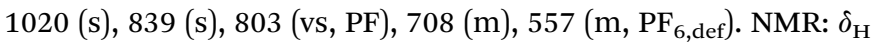
$\left(400 \mathrm{MHz}, \mathrm{CD}_{2} \mathrm{Cl}_{2}\right) 2.33\left(3 \mathrm{H}, \mathrm{s}, \mathrm{H}^{5}{ }_{6}\right), 4.11\left(3 \mathrm{H}, \mathrm{s}, \mathrm{H}^{15}{ }_{6}\right), 7.93(6 \mathrm{H}$, $\left.\mathrm{m}, \mathrm{H}^{10 / 10 / 20 / 20}{ }_{3 / 4 / 3 / 4}\right), 8.04(1 \mathrm{H}, \mathrm{s}, \mathrm{NH}), 8.12\left(2 \mathrm{H}, \mathrm{d},{ }^{3} J_{\mathrm{HH}}=8.3 \mathrm{~Hz}\right.$, $\left.\mathrm{H}^{5}{ }_{3}\right), 8.19\left(2 \mathrm{H}, \mathrm{d},{ }^{3} J_{\mathrm{HH}}=8.4 \mathrm{~Hz}, \mathrm{H}_{2}^{5}\right), 8.24\left(4 \mathrm{H}, \mathrm{m}, \mathrm{H}_{2 / 2}^{10 / 20}\right), 8.34$ $\left(2 \mathrm{H}, \mathrm{d},{ }^{3} J_{\mathrm{HH}}=8.3 \mathrm{~Hz}, \mathrm{H}^{15}{ }_{2}\right), 8.55\left(2 \mathrm{H}, \mathrm{d},{ }^{3} J_{\mathrm{HH}}=8.3 \mathrm{~Hz}, \mathrm{H}^{15}{ }_{3}\right)$, $9.37\left(8 \mathrm{H}, \mathrm{m}, \mathrm{H}^{2,3,7,8,12,13,17,18}\right) ; \delta_{\mathrm{C}}\left(100 \mathrm{MHz}, \mathrm{CD}_{2} \mathrm{Cl}_{2}\right) 24.9(\mathrm{~s}$, $\left.\mathrm{C}_{6}^{5}{ }_{6}\right), 53.2\left(\mathrm{~s}, \mathrm{C}^{15}{ }_{6}\right), 119.2\left(\mathrm{~s}, \mathrm{C}_{3}^{5}\right), 122.6\left(\mathrm{~s}, \mathrm{C}^{15}\right), 124.5\left(\mathrm{~s}, \mathrm{C}^{10 / 20}\right)$, $124.8\left(\mathrm{~s}, \mathrm{C}^{5}\right), 128.4\left(\mathrm{~s}, \mathrm{C}^{10 / 20}{ }_{3 / 3}\right), 129.3\left(\mathrm{~s}, \mathrm{C}^{15}{ }_{3}\right), 130.2\left(\mathrm{~s}, \mathrm{C}^{10 / 20}{ }_{4 / 4}\right)$, $132.0\left(\mathrm{~s}, \mathrm{C}^{15}{ }_{4}\right.$ ), 132.5-133.3 (multiple $\left.\mathrm{s}, \mathrm{C}^{2 / 3 / 7 / 8 / 12 / 13 / 17 / 18}\right), 134.8(\mathrm{~s}$, $\mathrm{C}^{10 / 20 / 15}{ }_{2 / 2 / 2}$ ), $135.4\left(\mathrm{~s}, \mathrm{C}^{5}{ }_{2}\right), 137.0-137.9$ (multiple $\mathrm{s}, \mathrm{C}^{1 / 4 / 6 / 9 / 11 / 14 / 16 / 19}$ ), $139.0\left(\mathrm{~s}, \mathrm{C}_{1 / 1}^{10 / 20}\right), 140.4\left(\mathrm{~s}, \mathrm{C}_{1}^{5}\right), 141.5\left(\mathrm{~s}, \mathrm{C}_{4}^{5}\right), 143.4\left(\mathrm{~s}, \mathrm{C}^{15}{ }_{1}\right), 169.9$ $\left(\mathrm{s}, \mathrm{C}^{15}{ }_{5}\right) . \delta_{\mathrm{P}}\left(162 \mathrm{MHz}, \mathrm{CD}_{2} \mathrm{Cl}_{2}\right)-143.5$ (sept, ${ }^{1} J_{\mathrm{PF}}=711 \mathrm{~Hz}$ ). MS (ESI): $m / z 924.01$ (100\%) [M] $]^{+}$. HR-MS (ESI): $m / z 924.2229$ (calcd for $\mathrm{C}_{48} \mathrm{H}_{33} \mathrm{AuN}_{5} \mathrm{O}_{3}$ : 924.2249). $\mathrm{CV}$ (Fc/Fc $\left.\mathrm{Fc}^{+}, \mathrm{THF}\right): E_{\frac{1}{2}} / \mathrm{V}-2.490$ (irrev.), $-2.300,-1.630,-0.990$.

[5-(4-(N-Acetylaminophenyl))-10,20-di(phenyl)-15-(4(carboxyphenyl))porphyrinato]gold(III) hexafluorophosphate $[\mathbf{4 a}]\left[\mathbf{P F}_{6}\right]$

5-(4-(N-Acetylaminophenyl))-10,20-di(phenyl)-15-(4-(carboxyphenyl))porphyrin IVa $(50 \mathrm{mg}, 0.07 \mathrm{mmol})$, potassium tetrachloridoaurate(III) (104 mg, $0.28 \mathrm{mmol}$ ) and sodium acetate (258 $\mathrm{mg}, 3.15 \mathrm{mmol})$ were dissolved in glacial acetic acid $(20 \mathrm{~mL})$. The reaction mixture was heated to reflux for $24 \mathrm{~h}$, allowed to cool to room temperature and diluted with dichloromethane $(100 \mathrm{~mL})$. The mixture was washed with water $(2 \times 50 \mathrm{~mL})$, saturated aqueous sodium carbonate solution $(2 \times 50 \mathrm{~mL})$ and water $(1 \times 50 \mathrm{~mL})$, dried over anhydrous magnesium sulfate and filtered. The filtrate was evaporated to dryness and the residue dissolved in dichloromethane $(50 \mathrm{~mL})$. The organic phase was stirred with a saturated aqueous solution of potassium hexafluorophosphate $(10 \mathrm{~mL})$ for $72 \mathrm{~h}$. The mixture was diluted with dichloromethane $(50 \mathrm{~mL})$ and washed with water $(2$ $\times 50 \mathrm{~mL}$ ), dried over anhydrous magnesium sulfate, and filtered. The filtrate was removed under reduced pressure and the residue purified by chromatography over silica [dichloromethane : methanol (10:1); $\left.R_{\mathrm{f}}=0.41\right]$ to yield $[\mathbf{4 a}]\left[\mathbf{P F}_{6}\right](24$ $\mathrm{mg}, 0.02 \mathrm{mmol}, 28 \%$ ) as a reddish-brown solid. $\mathrm{C}_{47} \mathrm{H}_{31} \mathrm{AuF}_{6}-$ $\mathrm{N}_{5} \mathrm{O}_{3} \mathrm{P}$ (1055.7). UV/Vis: $\lambda_{\max }(\mathrm{MeOH}) / \mathrm{nm} 408\left(\varepsilon / \mathrm{M}^{-1} \mathrm{~cm}^{-1}\right.$ 204 000), 522 (12 300). IR: $\nu_{\max } / \mathrm{cm}^{-1}$ 2955, 2914, 2872 (m, OH), 1712 (m, CO $\mathrm{CO}_{\text {acid }}$ ), 1695 (m, CO $\mathrm{COmide}_{\text {ame }}, 1638$ (s), 1618 (s), 1432 (s), 1385 (s), 1363 (s), 1232 (s, COC $_{\mathrm{def}}$ ), 1155 (s), 1121 (m), 839 (vs, PF), $775(\mathrm{~s}), 770(\mathrm{~s}), 558\left(\mathrm{~s}, \mathrm{PF}_{6, \mathrm{def}}\right)$. NMR: $\delta_{\mathrm{H}}\left(400 \mathrm{MHz}, \mathrm{CD}_{3} \mathrm{OD}\right)$ $2.33\left(3 \mathrm{H}, \mathrm{s}, \mathrm{H}_{6}^{5}\right), 7.95\left(6 \mathrm{H}, \mathrm{m}, \mathrm{H}^{10 / 10 / 20 / 20}{ }_{3 / 4 / 3 / 4}\right), 8.12\left(2 \mathrm{H}, \mathrm{d},{ }^{3} J_{\mathrm{HH}}\right.$ $\left.=8.3 \mathrm{~Hz}, \mathrm{H}^{5}{ }_{3}\right), 8.20\left(2 \mathrm{H}, \mathrm{d},{ }^{3} J_{\mathrm{HH}}=8.4 \mathrm{~Hz}, \mathrm{H}^{5}{ }_{2}\right), 8.24\left(2 \mathrm{H}, \mathrm{d},{ }^{3} J_{\mathrm{HH}}\right.$ $\left.=8.3 \mathrm{~Hz}, \mathrm{H}^{15}{ }_{2}\right), 8.26\left(4 \mathrm{H}, \mathrm{m}, \mathrm{H}^{10 / 20}{ }_{2 / 2}\right), 8.45\left(2 \mathrm{H}, \mathrm{d},{ }^{3} J_{\mathrm{HH}}=8.3\right.$ $\left.\mathrm{Hz}, \mathrm{H}^{15}{ }_{3}\right), 9.36\left(8 \mathrm{H}, \mathrm{m}, \mathrm{H}^{2,3,7,8,12,13,17,18}\right) ; \delta_{\mathrm{C}}\left(100 \mathrm{MHz}, \mathrm{CD}_{3} \mathrm{OD}\right)$ $24.0\left(\mathrm{~s}, \mathrm{C}_{6}^{5}\right), 120.1\left(\mathrm{~s}, \mathrm{C}^{5}{ }^{5}\right), 124.8\left(\mathrm{~s}, \mathrm{C}^{15}\right), 125.0\left(\mathrm{~s}, \mathrm{C}^{10 / 20}\right), 127.1$ $\left(\mathrm{s}, \mathrm{C}^{5}\right), 127.4\left(\mathrm{~s}, \mathrm{C}^{10 / 20}{ }_{3 / 3}\right), 128.1\left(\mathrm{~s}, \mathrm{C}^{15}{ }_{3}\right), 129.1\left(\mathrm{~s}, \mathrm{C}^{10 / 20}{ }_{4 / 4}\right)$, $131.4\left(\mathrm{~s}, \mathrm{C}^{15}{ }_{4}\right), 131.9\left(\mathrm{br} \mathrm{s}, \mathrm{C}^{2 / 3 / 7 / 8 / 12 / 13 / 17 / 18}\right), 133.5\left(\mathrm{~s}, \mathrm{C}^{5}{ }_{2}\right), 134.8$ $\left(\mathrm{s}, \mathrm{C}^{10 / 20 / 15}{ }_{2 / 2 / 2}\right), 136.9\left(\mathrm{br} \mathrm{s}, \mathrm{C}^{1 / 4 / 6 / 9 / 11 / 14 / 16 / 19}\right), 138.7\left(\mathrm{~s}, \mathrm{C}^{10 / 20}{ }_{1 / 1}\right)$, $140.0\left(\mathrm{~s}, \mathrm{C}^{5}{ }_{1}\right), 140.2\left(\mathrm{~s}, \mathrm{C}^{15}{ }_{1}\right), 141.4\left(\mathrm{~s}, \mathrm{C}^{5}{ }_{4}\right), 165.9\left(\mathrm{~s}, \mathrm{C}^{15}{ }_{5}\right), 170.9$ $\left(\mathrm{s}, \mathrm{C}^{5}{ }_{5}\right) \cdot \delta_{\mathrm{P}}\left(162 \mathrm{MHz}, \mathrm{CD}_{3} \mathrm{OD}\right)-143.5\left(\mathrm{sept},{ }^{1} J_{\mathrm{PF}}=710 \mathrm{~Hz}\right) . \mathrm{MS}$ (ESI): $m / z 910.18$ (100\%) [M] $]^{+}$. HR-MS (ESI): $m / z 910.2115$ (calcd for $\mathrm{C}_{47} \mathrm{H}_{31} \mathrm{AuN}_{5} \mathrm{O}_{3}$ : 910.2093). $\mathrm{CV}\left(\mathrm{Fc} / \mathrm{Fc}^{+}, \mathrm{MeOH}\right): E_{\frac{1}{2}} / \mathrm{V}-1.030$.
[5-(4-(N-Acetylaminophenyl))-10,20-di((4-butoxy)phenyl)-15-(4(carboxyphenyl))porphyrinato]gold(III) hexafluorophosphate $[\mathbf{4 b}]\left[\mathrm{PF}_{6}\right]$

5-(4-(N-Acetylaminophenyl))-10,20-di((4-butoxy)phenyl)-15-(4(carboxyphenyl))porphyrin IVb $(75 \mathrm{mg}, 0.09 \mathrm{mmol})$, potassium tetrachloridoaurate(III) (133 mg, $0.36 \mathrm{mmol})$ and sodium acetate (328 $\mathrm{mg}, 4.00 \mathrm{mmol}$ ) were dissolved in glacial acetic acid (40 $\mathrm{mL}$ ). The reaction mixture was heated to reflux for $24 \mathrm{~h}$, allowed to cool to room temperature, and diluted with dichloromethane $(200 \mathrm{~mL})$. The mixture was washed with water $(2 \times 100 \mathrm{~mL})$, saturated aqueous sodium carbonate solution $(2 \times 100 \mathrm{~mL})$ and water $(1 \times 100 \mathrm{~mL})$, dried over anhydrous magnesium sulfate and filtered. The filtrate was evaporated to dryness and the residue dissolved in dichloromethane $(100 \mathrm{~mL})$. The organic phase was stirred with a saturated aqueous solution of potassium hexafluorophosphate $(20 \mathrm{~mL})$ for $72 \mathrm{~h}$. The mixture was diluted with dichloromethane $(100 \mathrm{~mL})$ and washed with water $(2 \times 50 \mathrm{~mL})$, dried over anhydrous magnesium sulfate and filtered. The filtrate was removed under reduced pressure and the residue purified by chromatography over silica [dichloromethane : methanol $\left.(10: 1) ; R_{\mathrm{f}}=0.40\right]$ to yield [4b] $\left[\mathbf{P F}_{6}\right](72$ $\mathrm{mg}, 0.06 \mathrm{mmol}, 66 \%)$ as a purple solid. $\mathrm{C}_{55} \mathrm{H}_{47} \mathrm{AuF}_{6} \mathrm{~N}_{5} \mathrm{O}_{5} \mathrm{P}$ (1199.9). UV/Vis: $\lambda_{\max }(\mathrm{THF}) / \mathrm{nm} 422\left(\varepsilon / \mathrm{M}^{-1} \mathrm{~cm}^{-1} 86000\right), 527$ (9100), 571 (3200). IR: $\nu_{\max } / \mathrm{cm}^{-1}$ 2957, 2924, 2870, 2855 (m, $\mathrm{OH}), 1716$ (sh, $\mathrm{CO}_{\text {acid }}$ ), 1699 (s, $\mathrm{CO}_{\text {amide }}$ ), 1605 (s), 1505 (m), 1247 (s, $\left.\mathrm{COC}_{\mathrm{def}}\right), 843$ (vs, PF), 804 (s), 558 (s, PF $\left.{ }_{6, \mathrm{def}}\right) . \mathrm{NMR}: \delta_{\mathrm{H}}$ $\left(400 \mathrm{MHz}, \mathrm{d}_{8}-\mathrm{THF}\right) 1.10\left(6 \mathrm{H}, \mathrm{t},{ }^{3} J_{\mathrm{HH}}=7.3 \mathrm{~Hz}, \mathrm{H}^{10 / 20}{ }_{8 / 8}\right), 1.66$ $\left(4 \mathrm{H}, \mathrm{m}, \mathrm{H}^{10 / 20}{ }_{7 / 7}\right), 1.96\left(4 \mathrm{H}, \mathrm{m}, \mathrm{H}^{10 / 20}{ }_{6 / 6}\right), 2.14\left(3 \mathrm{H}, \mathrm{s}, \mathrm{H}^{5}{ }_{6}\right), 4.30$ $\left(2 \mathrm{H}, \mathrm{t},{ }^{3} \mathrm{~J}_{\mathrm{HH}}=6.4 \mathrm{~Hz}, \mathrm{H}^{10 / 20}{ }_{5 / 5}\right), 7.44\left(2 \mathrm{H}, \mathrm{d},{ }^{3} \mathrm{~J}_{\mathrm{HH}}=7.4 \mathrm{~Hz}\right.$, $\left.\mathrm{H}^{10 / 20}{ }_{3 / 3}\right), 8.12\left(4 \mathrm{H}, \mathrm{m}, \mathrm{H}^{5 / 5}{ }_{2 / 3}\right), 8.17\left(2 \mathrm{H}, \mathrm{d},{ }^{3} \mathrm{~J}_{\mathrm{HH}}=7.3 \mathrm{~Hz}, \mathrm{H}_{2 / 2}^{10 / 20}\right)$, $8.37\left(2 \mathrm{H}, \mathrm{d},{ }^{3} J_{\mathrm{HH}}=7.1 \mathrm{~Hz}, \mathrm{H}^{15}{ }_{2}\right), 8.53\left(2 \mathrm{H}, \mathrm{d},{ }^{3} J_{\mathrm{HH}}=7.0 \mathrm{~Hz}, \mathrm{H}^{15}{ }_{3}\right)$, $9.36\left(8 \mathrm{H}, \mathrm{m}, \mathrm{H}^{2,3,7,8,12,13,17,18}\right), 9.48(1 \mathrm{H}, \mathrm{s}, \mathrm{NH}) ; \delta_{\mathrm{C}}(100$ $\mathrm{MHz}, \mathrm{d}_{8}$-THF) $14.3\left(\mathrm{~s}, \mathrm{C}^{10 / 20}{ }_{8 / 8}\right), 20.4\left(\mathrm{~s}, \mathrm{C}^{10 / 20}{ }_{7 / 7}\right), 24.4\left(\mathrm{~s}, \mathrm{C}_{6}^{5}\right)$, $32.5\left(\mathrm{~s}, \mathrm{C}^{10 / 20}{ }_{6 / 6}\right), 67.6\left(\mathrm{~s}, \mathrm{C}^{10 / 20}{ }_{5 / 5}\right), 114.7\left(\mathrm{~s}, \mathrm{C}^{10 / 20}{ }_{3 / 3}\right), 118.8\left(\mathrm{~s}, \mathrm{C}_{3}^{5}\right)$, $122.9\left(\mathrm{~s}, \mathrm{C}^{15}\right), 124.7\left(\mathrm{~s}, \mathrm{C}^{10 / 20}\right), 125.1\left(\mathrm{~s}, \mathrm{C}^{5}\right), 129.8\left(\mathrm{~s}, \mathrm{C}^{15}{ }_{3}\right), 131.7$ $\left(\mathrm{s}, \mathrm{C}^{10 / 20}{ }_{1 / 1}\right), 132.5\left(\mathrm{~s}, \mathrm{C}^{15}{ }_{4}\right), 133.1-133.8\left(\mathrm{br} \mathrm{s}, \mathrm{C}^{2 / 3 / 7 / 8 / 12 / 13 / 17 / 18}\right)$, $135.2\left(\mathrm{~s}, \mathrm{C}^{15}{ }_{2}\right), 135.7\left(\mathrm{~s}, \mathrm{C}^{5}{ }_{2}\right), 136.6\left(\mathrm{~s}, \mathrm{C}^{10 / 20}{ }_{2 / 2}\right), 137.6\left(\mathrm{~s}, \mathrm{C}_{1}^{5}\right), 138.5$ (br s, $\left.\mathrm{C}^{1 / 4 / 6 / 9 / 11 / 14 / 16 / 19}\right), 141.3\left(\mathrm{~s}, \mathrm{C}^{5}{ }_{4}\right), 143.9\left(\mathrm{~s}, \mathrm{C}^{15}{ }_{1}\right), 161.5(\mathrm{~s}$, $\left.\mathrm{C}^{10 / 20}{ }_{4 / 4}\right), 167.5\left(\mathrm{~s}, \mathrm{C}^{15}{ }_{5}\right), 169.3\left(\mathrm{~s}, \mathrm{C}_{5}^{5}\right) \cdot \delta_{\mathrm{P}}\left(162 \mathrm{MHz}, \mathrm{d}_{8}\right.$-THF $)$ -143.5 (sept, ${ }^{1} J_{\mathrm{PF}}=710 \mathrm{~Hz}$ ). MS (ESI): $m / z 1054.26(100 \%)[\mathrm{M}]^{+}$. HR-MS (ESI): $m / z 1054.3218$ (calcd for $\mathrm{C}_{55} \mathrm{H}_{47} \mathrm{AuN}_{5} \mathrm{O}_{5}: 1054.3243$ ). $\mathrm{CV}\left(\mathrm{Fc} / \mathrm{Fc}^{+}, \mathrm{THF}\right): E_{\frac{1}{2}} / \mathrm{V}-2.450,-1.745,-1.070$.

\section{[5-(4-(N-Acetylaminophenyl))-10,20-bis(4-}

(trifluoromethylphenyl))-15-(4-(carboxyphenyl))porphyrinato] gold(III) hexafluorophosphate $[4 \mathrm{c}]\left[\mathrm{PF}_{6}\right]$

5-(4-(N-Acetylaminophenyl))-10,20-bis(4-(tri-

fluoromethylphenyl))-15-(4-(carboxyphenyl))porphyrin IVc (63 $\mathrm{mg}, 0.07 \mathrm{mmol}$ ), potassium tetrachlorido aurate(III) (104 mg, $0.28 \mathrm{mmol}$ ), and sodium acetate $(258 \mathrm{mg}, 3.15 \mathrm{mmol})$ were dissolved in glacial acetic acid $(20 \mathrm{~mL})$. The reaction mixture was heated to reflux for $24 \mathrm{~h}$, allowed to cool to room temperature and diluted with dichloromethane $(100 \mathrm{~mL})$. The mixture was washed with water $(2 \times 50 \mathrm{~mL})$, saturated aqueous sodium carbonate solution $(2 \times 50 \mathrm{~mL})$ and water $(1 \times 50 \mathrm{~mL})$, dried over anhydrous magnesium sulfate and filtered. The filtrate was 
evaporated to dryness and the residue dissolved in dichloromethane $(50 \mathrm{~mL})$. The organic phase was stirred with a saturated aqueous solution of potassium hexafluorophosphate (10 $\mathrm{mL}$ ) for $72 \mathrm{~h}$. The mixture was diluted with dichloromethane (50 $\mathrm{mL})$ and washed with water $(2 \times 50 \mathrm{~mL})$, dried over anhydrous magnesium sulfate and filtered. The filtrate was removed under reduced pressure and the residue purified by chromatography over silica [dichloromethane : methanol (10:1); $R_{\mathrm{f}}=0.30$ ] to yield [4c] $\left[\mathbf{P F}_{6}\right](71 \mathrm{mg}, 0.06 \mathrm{mmol}, 85 \%)$ as a purple, crystalline solid. $\mathrm{C}_{49} \mathrm{H}_{29} \mathrm{AuF}_{12} \mathrm{~N}_{5} \mathrm{O}_{3} \mathrm{P}$ (1191.7). UV/Vis: $\lambda_{\max }(\mathrm{THF}) / \mathrm{nm} 409$ $\left(\varepsilon / \mathrm{M}^{-1} \mathrm{~cm}^{-1} 170000\right), 525$ (15 100), 571 (3200). IR: $\nu_{\max } / \mathrm{cm}^{-1}$ 2959, 2922, 2851 (w, OH), 1721 (s, CO acid), 1689 (s, CO amide), 1616 (m), 1591 (m), 1515 (m), 1406 (m), 1324 (vs, CF), 1168 (m), 1126 (m), 1109 (m), 1069 (s), 1034 (m), 1017 (s), 842 (vs, PF), 820 $(\mathrm{s}), 800(\mathrm{~s}), 706(\mathrm{~m}), 556$ (s, $\left.\mathrm{PF}_{6, \mathrm{def}}\right)$. NMR: $\delta_{\mathrm{H}}\left(400 \mathrm{MHz}, \mathrm{d}_{8}-\mathrm{THF}\right)$ $2.21\left(3 \mathrm{H}, \mathrm{s}, \mathrm{H}^{5}{ }_{6}\right), 8.08\left(2 \mathrm{H}, \mathrm{d},{ }^{3} J_{\mathrm{HH}}=8.2 \mathrm{~Hz}, \mathrm{H}^{5}{ }_{3}\right), 8.14(2 \mathrm{H}, \mathrm{d}$, $\left.{ }^{3} J_{\mathrm{HH}}=8.2 \mathrm{~Hz}, \mathrm{H}^{5}{ }_{2}\right), 8.25\left(2 \mathrm{H}, \mathrm{d},{ }^{3} J_{\mathrm{HH}}=7.5 \mathrm{~Hz}, \mathrm{H}^{10 / 20}{ }_{2 / 2}\right), 8.39$ $\left(2 \mathrm{H}, \mathrm{d},{ }^{3} \mathrm{~J}_{\mathrm{HH}}=7.1 \mathrm{~Hz}, \mathrm{H}^{15}{ }_{2}\right), 8.53\left(2 \mathrm{H}, \mathrm{d},{ }^{3} J_{\mathrm{HH}}=7.5 \mathrm{~Hz}, \mathrm{H}^{10 / 20}{ }_{3 / 3}\right)$, $8.53\left(2 \mathrm{H}, \mathrm{d},{ }^{3} \mathrm{~J}_{\mathrm{HH}}=7.5 \mathrm{~Hz}, \mathrm{H}^{15}{ }_{3}\right), 9.40\left(8 \mathrm{H}, \mathrm{m}, \mathrm{H}^{2,3,7,8,12,13,17,18}\right)$, $9.41(1 \mathrm{H}, \mathrm{s}, \mathrm{NH}) ; \delta_{\mathrm{C}}\left(100 \mathrm{MHz}, \mathrm{d}_{8}\right.$-THF) $24.3\left(\mathrm{~s}, \mathrm{C}^{5}{ }_{6}\right), 118.8(\mathrm{~s}$, $\left.\mathrm{C}^{5}{ }_{3}\right), 122.9\left(\mathrm{~s}, \mathrm{C}^{5}\right), 123.5\left(\mathrm{~s}, \mathrm{C}^{15}\right), 124.3\left(\mathrm{~s}, \mathrm{C}^{10 / 20}\right), 125.6(\mathrm{~s}$, $\left.\mathrm{C}^{10 / 20}{ }_{2 / 2}\right), 127.0\left(\mathrm{~s}, \mathrm{C}^{10 / 20}{ }_{4 / 4}\right), 129.8\left(\mathrm{~s}, \mathrm{C}^{15}{ }_{3}\right), 132.4\left(\mathrm{~s}, \mathrm{C}_{4}^{15}\right)$, 133.1-133.8 (multiple s, $\mathrm{C}^{2 / 3 / 7 / 8 / 12 / 13 / 17 / 18}$ ), 135.3 (s, $\mathrm{C}^{15}{ }_{2}$ ), $135.7\left(\mathrm{~s}, \mathrm{C}^{5 / 5 / 10 / 10}{ }_{2 / 3 / 2 / 3}\right.$ ), $137.7\left(\mathrm{~s}, \mathrm{C}^{5}{ }_{1}\right.$ ), 137.9-138.7 (multiple $\mathrm{s}$, $\left.\mathrm{C}^{1 / 4 / 6 / 9 / 11 / 14 / 16 / 19}\right), 142.2\left(\mathrm{~s}, \mathrm{C}_{4}^{5}\right), 143.9\left(\mathrm{~s}, \mathrm{C}_{1 / 1 / 1}^{10 / 15 / 20}\right), 161.5(\mathrm{~s}$, $\left.\mathrm{C}_{4 / 4}^{10 / 20}\right), 167.5\left(\mathrm{~s}, \mathrm{C}^{15}{ }_{5}\right), 169.2\left(\mathrm{~s}, \mathrm{C}^{5}{ }_{5}\right) . \delta_{\mathrm{P}}\left(162 \mathrm{MHz}, \mathrm{d}_{8}-\mathrm{THF}\right)$ -143.3 (sept, ${ }^{1} J_{\mathrm{PF}}=711 \mathrm{~Hz}$ ). MS (ESI): $m / z 1045.97$ (100\%) $[\mathrm{M}]^{+}$. HR-MS (ESI): $m / z$ 1046.1863 (calcd for $\mathrm{C}_{49} \mathrm{H}_{29} \mathrm{AuF}_{6} \mathrm{~N}_{5} \mathrm{O}_{3}$ : 1046.1840). $\mathrm{CV}$ (Fc/Fc $\left.{ }^{+}, \mathrm{THF}\right): E_{\frac{1}{2}} / \mathrm{V}-2.300,-1.590,-0.990$.

\section{Conclusions}

Auration of meso-tetraaryl substituted $\mathrm{AB}_{2} \mathrm{C}$ porphyrins with $\mathrm{KAuCl}_{4}$ in the presence of HOAc/NaOAc cleanly gives the corresponding gold(III) porphyrinato complex cations. Aminosubstituted porphyrins are $\mathrm{N}$-acetylated under these conditions and have to be prepared from the corresponding nitrosubstituted gold(III) porphyrins by reduction with $\mathrm{SnCl}_{2} / \mathrm{HCl}$. The gold(III) complexes can be reduced at least three times. The potentials slightly depend on the electron withdrawing and donating nature of the substituents. The first reduction is addressed by UV/Vis spectroelectrochemistry and by EPR spectroscopy. Upon one-electron reduction, the Soret band experiences a small bathochromic shift. The intensity of the Soret band of the electron rich complexes $[2 \mathbf{a}]^{+}\left(\mathrm{R}^{2}=\mathrm{NH}_{2}\right)$ and $[\mathbf{4 b}]^{+}$ $\left(\mathrm{R}^{3}=\mathrm{O}^{n} \mathrm{Bu}\right)$ slightly increases upon reduction while all other neutral complexes feature less intense Soret bands as compared to their parent $\mathrm{Au}^{\mathrm{III}}$ complexes. These spectral data clearly suggest the presence of an unreduced porphyrinato ligand in all cases under these conditions. Chemical one-electron reduction of the porphyrinato gold(III) hexafluorophosphate salts by cobaltocene yields the corresponding $\mathrm{Au}^{\mathrm{II}}$ porphyrin complexes with a characteristic EPR pattern displaying hyperfine coupling to ${ }^{197} \mathrm{Au}$ and ${ }^{14} \mathrm{~N}$. The degree of ${ }^{197} \mathrm{Au}$ hfc and $g$ anisotropy places the gold contribution to the spin density in (tetraphenylporphyrinato)gold(II) complexes in between that of $\left[\mathrm{Au}(\mathrm{en})_{2}\right]^{2+}$ (ref. 15) and the neutral gold hematoporphyrin IX complex. ${ }^{13 e}$ DFT calculations fully support the metal centred reduction in all cases, essentially irrespective of the substituent at the meso aryl groups. Only, the nitro substituent reduction competes significantly with the $\mathrm{Au}^{\mathrm{III}}$ reduction and a valence isomeric equilibrium between the $\mathrm{Au}^{\mathrm{II}}$ valence isomer and the nitro $\pi$ radical anion valence isomer is established. DFT calculations suggest that the position of the counterion triggers the position of the equilibria between the different valence isomers that interconvert by an intramolecular electron transfer process. These findings allows the usage of meso-substituted $\mathrm{Au}^{\mathrm{III}}$ porphyrins as electron acceptors and electron storage materials in photo-induced redox processes, almost irrespective of the substitution pattern. Hence, the substituents fine-tune the redox potential or other properties such as solubility without compromising the thermodynamically preferred metal site of one-electron reduction. Combination of electronaccepting gold(III) porphyrins bearing carboxylic acid, amine and amide substituents, as introduced in this report, with lightharvesting porphyrins and electron donating porphyrins via amide connectivity ${ }^{\mathbf{1 7}}$ are currently explored in our laboratory and will be reported in due course.

\section{Acknowledgements}

The authors S. P., A. W. v. L. and K. H. thank the Center of Innovative and Emerging Materials (CINEMA) for financial support. We thank the students Katrin Limberg and Heike Pfaff for preparative assistance.

\section{Notes and references}

1 (a) D. Gust and T. A. Moore, in The Porphyrin Handbook, ed. K. M. Kadish, K. M.Smith and R. Guilard, Academic Press, San Diego, CA, 2000, vol. 8, p. 153; (b) D. Gust, T. A. Moore and A. L. Moore, in Electron Transfer in Chemistry, ed. V. Balzani, Wiley-VCH, Weinheim, 2001, vol. 3, p. 272; (c) S. Fukuzumi and H. Imahori, in Electron Transfer in Chemistry, ed. V. Balzani, Wiley-VCH, Weinheim, 2001, vol. 2, p. 927; (d) S. Fukuzumi and D. M. Guldi, in Electron Transfer in Chemistry, ed. V. Balzani, Wiley-VCH, Weinheim, 2001, vol. 2, p. 270.

2 (a) S. Ishihara, J. Labuta, W. Van Rossom, D. Ishikawa, K. Minami, J. P. Hill and K. Ariga, Phys. Chem. Chem. Phys., 2014, 16, 9713; (b) N. A. Rakow and K. S. Suslick, Nature, 2000, 406, 710; (c) N. A. Rakow, A. Sen, M. C. Janzen, J. B. Ponder and K. S. Suslick, Angew. Chem., Int. Ed., 2005, 44, 4528; (d) S. H. Lim, L. Feng, J. W. Kemling, C. J. Musto and K. S. Suslick, Nat. Chem., 2009, 1, 562; (e) P. Heier, N. D. Boscher, P. Choquet and K. Heinze, Inorg. Chem., 2014, 53, 11086; ( $f$ ) P. Heier, T. Bohn, P. Choquet, N. D. Boscher and K. Heinze, J. Mater. Chem. A, 2014, 2, 1560; (g) N. D. Boscher, T. Bohn, P. Heier, F. Moisy, B. Untereiner, K. Heinze and P. Choquet, Sens. Actuators, B, 2014, 191, 553; (h) P. Heier, C. Förster, D. Schollmeyer, N. Boscher, P. Choquet and K. Heinze, Dalton Trans., 2013, 42, 906 . 
3 (a) M. Ethirajan, Y. Chen, P. Joshia and R. K. Pandey, Chem. Soc. Rev., 2011, 40, 340; (b) E. D. Sternberg, D. Dolphin and C. Brücker, Tetrahedron, 1998, 54, 4151.

4 (a) L. He, T. Chen, Y. You, H. Hu, W. Zheng, W.-L. Kwong, T. Zou and C.-M. Che, Angew. Chem., Int. Ed., 2014, 53, 12532; (b) C. T. Lum, R. W.-Y. Sun, T. Zou and C.-M. Che, Chem. Sci., 2014, 5, 1579; (c) C.-M. Che and R. W.-Y. Sun, Chem. Commun., 2011, 47, 9554; (d) R. W.-Y. Sun, C. K.-L. Li, D.-L. Ma, J. J. Yan, C.-N. Lok, C.-H. Leung, N. Zhu and C.-M. Che, Chem.-Eur. J., 2010, 16, 3097; (e) R. W.-Y. Sun and C.-M. Che, Coord. Chem. Rev., 2009, 253, 1682; $(f)$ C.-M. Che, R. W.-Y. Sun, W.-Y. Yu, C.-B. Ko, N. Zhu and H. Sun, Chem. Commun., 2003, 1718.

5 (a) C.-Y. Zhou, P. W. H. Chan and C.-M. Che, Org. Lett., 2006, 8, 325; (b) A. Nijamudheen, D. Jose and A. Datta, J. Phys. Chem. C, 2011, 115, 2187.

6 D. Tanaka, Y. Inuta, M. Sakamoto, A. Furube, M. Haruta, Y.-G. So, K. Kimoto, I. Hamada and T. Teranishi, Chem. Sci., 2014, 5, 2007.

7 (a) E. Göransson, J. Boixel, J. Fortage, D. Jacquemin, H.-C. Becker, E. Blart, L. Hammarström and F. Odobel, Inorg. Chem., 2012, 51, 11500; (b) K. Ohkubo, R. Garcia, P. J. Sintic, T. Khoury, M. J. Crossley, K. M. Kadish and S. Fukuzumi, Chem.-Eur. J., 2009, 15, 10493; (c) J. Fortage, A. Scarpaci, L. Viau, Y. Pellegrin, E. Blart, M. Falkenström, L. Hammarström, I. Asselberghs, R. Kellens, W. Libaers, K. Clays, M. P. Eng and F. Odobel, Chem.-Eur. J., 2009, 15, 9058; (d) J. Fortage, J. Boixel, E. Blart, H. C. Becker and F. Odobel, Inorg. Chem., 2009, 48, 518; (e) J. Fortage, J. Boixel, E. Blart, L. Hammarström, H. C. Becker and F. Odobel, Chem.-Eur. J., 2008, 14, 3467; (f) K. Ohkubo, P. J. Sintic, N. V. Tkachenko, H. Lemmetyinen, W. E. Z. Ou, J. Shao, K. M. Kadish, M. J. Crossley and S. Fukuzumi, Chem. Phys., 2006, 326, 3; $(g)$ S. Fukuzumi, K. Ohkubo, W. E. Z. Ou, J. Shao, K. M. Kadish, J. A. Hutchison, K. P. Ghiggino, P. J. Sintic and M. J. Crossley, J. Am. Chem. Soc., 2003, 125, 14984; (h) K. Kilså, J. Kajanus, A. N. Macpherson, J. Mårtensson and B. Albinsson, J. Am. Chem. Soc., 2001, 123, 3069; (i) E. K. L. Yeow, P. J. Sintic, N. M. Cabral, J. N. H. Reek, M. J. Crossley and K. P. Ghiggino, Phys. Chem. Chem. Phys., 2000, 2, 4281; (j) I. M. Dixon, J.-P. Collin, J.-P. Sauvage, F. Barigelletti and L. Flamigni, Angew. Chem., Int. Ed., 2000, 39, 1292; (k) D. B. Amabilino and J.-P. Sauvage, New J. Chem., 1998, 395; (l) A. Harriman, F. Odobel and J.-P. Sauvage, J. Am. Chem. Soc., 1995, 117, 9461; $(m)$ V. Heitz, S. Chardon-Noblat and J.-P. Sauvage, Tetrahedron Lett., 1991, 32, 197; (n) A. M. Brun, A. Harriman, V. Heitz and J.-P. Sauvage, J. Am. Chem. Soc., 1991, 113, 8657.

8 (a) Z. Abou-Gamra, A. Harriman and P. Neta, J. Chem. Soc., Faraday Trans. 2, 1986, 2337; (b) A. Antipas, D. Dolphin, M. Gouterman and E. C. Johnson, J. Am. Chem. Soc., 1978, 100, 7705; (c) M. E. Jamin and R. T. Iwamoto, Inorg. Chim. Acta, 1978, 27, 135.

9 K. M. Kadish, W. E. Z. Ou, J. Shao, P. J. Sintic, K. Ohkubo, S. Fukuzumi and M. J. Crossley, Chem. Commun., 2002, 356.
10 (a) J. H. Waters and H. B. Gray, J. Am. Chem. Soc., 1965, 87, 3534; (b) R. L. Schlupp and A. H. Maki, Inorg. Chem., 1974, 13, 44; (c) A. J. Blake, J. A. Greig, A. J. Holder, T. I. Hyde, A. Taylor and M. Schröder, Angew. Chem., Int. Ed. Engl., 1990, 29, 197; (d) A. P. Koley, S. Purohit, S. Ghosh, L. S. Prasad and P. T. Manoharan, J. Chem. Soc., Dalton Trans., 1988, 2607; (e) A. P. Koley, S. Purohit, L. S. Prasad, S. Ghosh and P. T. Manoharan, Inorg. Chem., 1992, 31, 305; ( f) A. P. Koley, L. S. Prasad, P. T. Manoharan and S. Ghosh, Inorg. Chim. Acta, 1992, 194, 219; $(g)$ L. Ihlo, M. Kampf, R. Böttcher and R. Kirmse, Z. Naturforsch., B: J. Chem. Sci., 2002, 57, 171; (h) M. Kampf, J. Griebel and R. Kirmse, Z. Anorg. Allg. Chem., 2004, 630, 2669; (i) M. Kampf, R.-M. Olk and R. Kirmse, Z. Anorg. Allg. Chem., 2002, 628, 34.

11 F. G. Herring, G. Hwang, K. C. Lee, F. Mistry, P. S. Phillips, H. Willner and F. Aubke, J. Am. Chem. Soc., 1992, 114, 1271. 12 S. Seidel and K. Seppelt, Science, 2000, 290, 117.

13 (a) Z. Ou, W. Zhu, Y. Fang, P. J. Sintic, T. Khoury, M. J. Crossley and K. M. Kadish, Inorg. Chem., 2011, 50, 12802; (b) A. Klein, in Spectroelectrochemistry, ed. W. Kaim and A. Klein, RSC publishing, 2008, p. 91; (c) Z. Ou, K. M. Kadish, W. E. J. Shao, P. J. Sintic, K. Ohkubo, S. Fukuzumi and M. J. Crossley, Inorg. Chem., 2004, 43, 2078; (d) S. Fukuzumi, K. Ohkubo, W. E. Z. Ou, J. Shao, K. M. Kadish, J. A. Hutchison, K. P. Ghiggino, P. J. Sintic and M. J. Crossley, J. Am. Chem. Soc., 2003, 125, 14984; (e) G. Gencheva, D. Tsekova, G. Gochev, D. Mehandjiev and P. R. Bontchev, Inorg. Chem. Commun., 2003, 6, 325.

14 (a) F. Mohr, S. Sanz, E. Vergara, E. Cerrada and M. Laguna, Gold Bull., 2006, 39, 212; (b) F. Mohr, S. Sanz, E. R. T. Tiekink and M. Laguna, Organometallics, 2006, 25, 3084; (c) E. Cerrada, M. Laguna, L. A. Mendez and F. Mohr, J. Am. Chem. Soc., 2005, 127, 852.

15 Z. Qu, L. Giurgiub and E. Roduner, Chem. Commun., 2006, 2507.

16 R. Timkovich and A. Tulinsky, Inorg. Chem., 1977, 4, 962.

17 (a) J. Melomedov, J. R. Ochsmann, M. Meister, F. Laquai and K. Heinze, Eur. J. Inorg. Chem., 2014, 2902; (b) J. Melomedov, J. R. Ochsmann, M. Meister, F. Laquai and K. Heinze, Eur. J. Inorg. Chem., 2014, 1984; (c) J. Melomedov, A. Wünsche von Leupoldt, M. Meister, F. Laquai and K. Heinze, Dalton Trans., 2013, 42, 9727; (d) K. Heinze and A. Reinhart, Dalton Trans., 2008, 469.

18 E. B. Fleischer and A. Laszlo, Inorg. Nucl. Chem. Lett., 1969, 5, 373.

19 (a) J.-C. Chambron, V. Heitz and J.-P. Sauvage, New J. Chem., 1997, 21, 237; (b) N. Solladié, J.-C. Chambron and J.-P. Sauvage, J. Am. Chem. Soc., 1999, 121, 3684.

20 (a) V. W.-W. Yam and E. C.-C. Cheng, Top. Curr. Chem., 2007, 281, 269-309; (b) M. P. Eng, T. Ljungdahl, J. Andréasson, J. Mårtensson and B. Albinsson, J. Phys. Chem. A, 2005, 109, 1776-1784.

21 J. Heinze, Angew. Chem., Int. Ed., 1984, 23, 831.

22 N. G. Connelly and W. E. Geiger, Chem. Rev., 1996, 96, 877. 
23 (a) D. H. Geske and A. H. Maki, J. Am. Chem. Soc., 1969, 82, 2671; (b) D. H. Geske, J. L. Ragle, M. A. Bambenek and A. L. Balch, J. Am. Chem. Soc., 1964, 86, 987.

24 S. Stoll and A. Schweiger, J. Magn. Reson., 2006, 178, 42.

25 M. J. Frisch, G. W. Trucks, H. B. Schlegel, G. E. Scuseria, M. A. Robb, J. R. Cheeseman, G. Scalmani, V. Barone, B. Mennucci, G. A. Petersson, H. Nakatsuji, M. Caricato, X. Li, H. P. Hratchian, A. F. Izmaylov, J. Bloino, G. Zheng, J. L. Sonnenberg, M. Hada, M. Ehara, K. Toyota, R. Fukuda, J. Hasegawa, M. Ishida, T. Nakajima, Y. Honda, O. Kitao, H. Nakai, T. Vreven, J. A. Montgomery Jr, J. E. Peralta, F. Ogliaro, M. Bearpark, J. J. Heyd,
E. Brothers, K. N. Kudin, V. N. Staroverov, R. Kobayashi, J. Normand, K. Raghavachari, A. Rendell, J. C. Burant, S. S. Iyengar, J. Tomasi, M. Cossi, N. Rega, J. M. Millam, M. Klene, J. E. Knox, J. B. Cross, V. Bakken, C. Adamo, J. Jaramillo, R. Gomperts, R. E. Stratmann, O. Yazyev, A. J. Austin, R. Cammi, C. Pomelli, J. W. Ochterski, R. L. Martin, K. Morokuma, V. G. Zakrzewski, G. A. Voth, P. Salvador, J. J. Dannenberg, S. Dapprich, A. D. Daniels, O. Farkas, J. B. Foresman, J. V. Ortiz, J. Cioslowski and D. J. Fox, Gaussian 09 (Revision A.02), Gaussian, Inc., Wallingford CT, 2009. 